\title{
DOES PRIVATE COUNTRY-BY-COUNTRY REPORTING IMPROVE THE TAX AND EARNINGS INFORMATION ENVIRONMENT FOR INVESTORS?
}

\author{
Jing Huang* \\ Pamplin College of Business \\ Virginia Tech \\ jjhuang@vt.edu \\ John X. Jiang \\ Eli Broad College of Business \\ Michigan State University \\ jiangj@msu.edu \\ Anh Persson \\ Gies College of Business \\ University of Illinois at Urbana-Champaign \\ apersson@illinois.edu
}

Current Version: September 2020

*Corresponding author.

We appreciate the helpful comments from Lillian Mills, Terry Shevlin, Kevin Markle, Jon Davis, David Godsell, and workshop participants at University of Illinois at Urbana-Champaign. Huang acknowledges financial support from the Accounting and Information Systems department at Virginia Tech. Jiang acknowledges financial support from the Department of Accounting and Information Systems at Michigan State and the Plante Moran Fellowship. Persson is grateful for the financial support from the Department of Accountancy at the Gies College of Business. All errors are our own. 


\title{
DOES PRIVATE COUNTRY-BY-COUNTRY REPORTING IMPROVE THE TAX AND EARNINGS INFORMATION ENVIRONMENT FOR INVESTORS?
}

\begin{abstract}
To combat base erosive tax avoidance, many countries have required multinational enterprises (MNEs) to disclose their income and economic activities to tax authorities on a country-by-country reporting (CbCR) basis from 2016 onwards. We examine whether this policy shock reduces the misalignment between MNEs' tax and economic activities and whether it generates positive information externalities for capital market investors. We use a novel approach based on the unexplained portion of analysts' tax forecast error to capture the extent of misalignment between MNEs' tax and economic activities as perceived by the capital market, and find that this misalignment declines after the adoptions of $\mathrm{CbCR}$. We further find that $\mathrm{CbCR}$ helps improve both tax and earnings information environment for investors, especially when firms have more misalignment prior to the $\mathrm{CbCR}$ adoptions. Our findings have important policy implications for governments worldwide that are trying to assess the economic consequences of $\mathrm{CbCR}$.
\end{abstract}

JEL Classification: H26, M41

Key Words: Taxation, Country-by-country Reporting, Tax Misalignment, Analysts' Forecasts Accuracy, Value Relevance 


\section{Introduction}

This paper examines the capital market implications of private country-by-country reporting $(\mathrm{CbCR})$ requirement, one of the most extensive international tax transparency plans to date. In recent years, multinational enterprises (MNEs) have been put in the spotlight for shifting income from countries where substantive economic activities take place to low-tax or tax haven countries where they have little economic presence (e.g., Drucker, 2010; Senate Hearing 112-781, 2012; Senate Hearing 113-90, 2013)). To align rights to tax with underlying economic activities, the Organisation for Economic Cooperation and Development (OECD) proposed a set of new transparency initiatives including the CbCR of Action Item 13. Specifically, the parent companies of large MNEs are required to file an annual report providing a country by country breakdown of its economic activities and tax liabilities to the tax authority of its residence. Through information exchange agreements, this report is then shared with all tax authorities where members of the MNEs operate. From 2016 to 2020, over 130 countries, including the United States, the United Kingdom, Japan, China, and the European Union, have adopted or introduced legislations to adopt CbCR (OECD, 2020).

CbCR is different from individual countries' tax transparency regulations in the past (e.g., Internal Revenue Services' Form 5471 on activities of certain U.S. foreign-controlled corporations). For the first time, large MNEs are obliged to provide the tax authorities around the world a comprehensive account of the company's global footprint as well as the tax obligations in every country where they operate. This widely coordinated international effort has significantly affected MNE's tax avoidance and operating decisions (De Simone and Olbert, 2019; Joshi, 2020). $\mathrm{CbCR}$ is also different from previous mandates that require firms to report tax information to the public (e.g., disclosure of significant subsidiaries in Exhibit 21 for U.S. companies, disclosure of 
corporate tax returns in Australia, or disclosure of subsidiary locations for U.K. firms) because $\mathrm{CbCR}$ only increases the information transparency for the tax authorities. ${ }^{1}$ Whereas there is a large body of literature that documents information externalities of mandatory public disclosure (e.g., Botosan and Stanford, 2005; De Franco et al., 2011; Welker, 1995), it is not well understood whether and how the private tax disclosure such as CbCR can influence the firm's external information environment.

Tax provides useful information for capital market participants to evaluate firm performance incremental to earnings (Mauler, 2019; Thomas and Zhang, 2014). However, the information value of tax for capital markets is distorted when MNEs engage in tax planning that separates income from economic activities. Consistently, prior research documents that more tax planning activities are associated with lower tax accrual quality (Choudhary et al., 2016), less accurate analysts' forecasts of tax expenses (Francis et al., 2019), and less value relevant taxable income (Ayers et al., 2009). In addition to the tax information environment, the misalignment between tax and economic activities further complicates business operation because of the complex and opaque organization structures used to achieve distortive tax practices (e.g., Levin and McCain, 2013). Similarly, Chen et al. (2018a) find that more tax motivated income shifting increases information asymmetry between the firm and outside investors. Therefore, it is more difficult for capital market information intermediaries such as analysts to interpret the source of earnings and evaluate potential firm growth, weakening the earnings information environment (Balakrishnan et al., 2019; Francis et al., 2019).

\footnotetext{
1 See Dyreng et al. (2020), Hoopes et al. (2018), and Dyreng et al. (2016) for a related discussion on public disclosure of tax information.
} 
As scholars and practitioners point out, the adoptions of CbCR should increase the risk of tax authorities in detecting and challenging tax avoidance activities. MNEs could therefore either substantiate their existing tax avoidance by increasing physical presence in low tax and tax haven countries or report more taxable income in countries where real operating activities occur, resulting in more taxes paid (Deloitte, 2017; Hanlon, 2018; Houlder, 2014). Such changes will reduce the misalignment between MNEs' taxable income and the underlying economic activities in each country. Early evidence on the adoption of CbCR in Europe supports both of these predictions. Specifically, De Simone and Olbert (2019) document that following CbCR adoptions, MNEs substantiated their existing tax avoidance by increasing economic activities in low tax and tax haven countries. Both De Simone and Olbert (2019) and Joshi (2020) find some evidence of reduced base erosive tax avoidance. Based on the early evidence on firm-level behavioral responses, we examine whether the capital market participants perceive a decline the firms' misalignment between tax and economic activities following $\mathrm{CbCR}$ adoptions.

We first develop a novel approach to measure how capital markets perceive the extent of misalignment between MNEs' economic activities and taxes. Different from prior research that separately examines the firm's internal decisions such as tax avoidance and economic operation (De Simone and Olbert, 2019; Joshi, 2020), our measure captures the firm's misalignment between tax and economic activities from the perspective of external capital markets. Financial analysts are sophisticated information intermediaries who provide high-quality earnings and tax forecasts for investors (Beyer et al., 2010; Bradshaw, 2012; Bratten et al., 2017). Prior research suggests that analysts begin with earnings forecasts based on the firm's economic activities, including the performance of its geographic segment (Botosan and Stanford, 2005). Analysts then make tax forecasts by mapping economic activities into tax estimates within the framework of tax laws 
(Mauler, 2019). A large misalignment between the firm's economic activities and its tax expense create difficulties for analysts to forecast the firm's tax expense accurately. We use a stylized model to capture the firm's tax misalignment based on the unexplained portion of analysts' tax forecast error relative to the firm's economic activities. We thus predict that, on average, capital markets perceive firms to have less misalignment following CbCR adoptions.

To provide evidence on how $\mathrm{CbCR}$ influences the firm's external information environment, we next examine whether major capital market participants (e.g., financial analysts and investors) experience an improvement in the quality of tax and earning information after CbCR adoptions. An increase in the alignment between economic activities and tax reduces the distortion to the tax estimates that is caused by tax planning and helps generate more accurate analysts' tax forecasts. For investors, to the extent that tax is more informative of underlying economic performance, this increases the value relevance of tax surprise incremental to earnings (Kerr, 2019). In addition to the impact on the quality of tax information, $\mathrm{CbCR}$ also reduces the use of complex and opaque organization structures that firms use to avoid tax (De Simone and Olbert, 2019). Better corporate transparency helps analysts understand the true nature of MNEs' worldwide economic activities and make it easier for investors to identify value relevant earnings information (Balakrishnan et al., 2019; Francis et al., 2019). Therefore, we expect that CbCR improves the quality of both tax and earnings information by increasing tax (earnings) forecast accuracy for analysts and increasing tax (earnings) value relevance for investors, and the information benefit should be greater for firms having more misalignment pre-CbCR.

To test our predictions based on an international sample, we combine Compustat North America and Compustat Global firms with analysts' forecast data from I/B/E/S between 2012 and 2019. The combined dataset gives the first insight into the tax and earnings information 
environment from major world economies adopting CbCR such as China, India, Japan, and the United States. Using both a difference-in-difference research design and regression discontinuity, we find that capital markets perceive less tax misalignment for CbCR firms post the policy implementation relative to firms not subject to $\mathrm{CbCR}$, consistent with prior studies (De Simone and Olbert, 2019; Joshi, 2020). Using a difference-in-difference design, we find that both tax and earnings forecast accuracy improves following CbCR adoptions, and the improvement in analysts' earnings forecast accuracy is more pronounced for firms with high levels of misalignment before the policy implementation. Specifically, the pretax (after-tax) earnings forecast errors of CbCR firms with high levels of pre-CbCR misalignment are $0.5(0.4)$ percentage points lower than those of firms not subject to $\mathrm{CbCR}$, and the difference is five (four) times larger than that of firms with low levels of pre-CbCR misalignment.

To test the effect of $\mathrm{CbCR}$ adoptions on the value relevance of tax and earnings information, we adapt the research design in Kerr (2019) for the difference-in-difference analysis. We measure earnings surprise using year-to-year change in earnings and measure the incremental tax surprise to earnings using the residual from the regression of the year-to-year change in tax expense on the year-to-year change in pretax earnings. The association between the 12-month buy-and-hold stock returns and the incremental tax surprise or earnings surprise captures the value relevance of incremental tax surprise or earnings surprise. We find that $\mathrm{CbCR}$ helps increase the value relevance of both tax and earnings surprise for $\mathrm{CbCR}$ firms relative to non-CbCR firms, though the statistical significance for earnings surprise is weak, and these effects are more pronounced for firms with high levels of misalignment prior to CbCR adoptions. Overall, our evidence implies that CbCR adoptions improve the tax and earnings information environment by mitigating the misalignment between tax and economic activities. 
Because of the significant compliance and tax controversy costs of CbCR (Hanlon, 2018), it is important to understand whether and how it benefits stakeholders. We believe that our findings have significant implications for market participants and for governments worldwide. Our study suggests that capital market investors perceive an increased alignment between tax rights and economic activities for MNEs after the adoptions of CbCR, which supports the overall policy objective of OECD's Base Erosion and Profit Shifting (BEPS) project. Furthermore, our findings suggest that $\mathrm{CbCR}$ generates positive capital market externalities through improving both tax and earnings information environment. Extending the stream of research that documents the benefits of tax transparency for external capital market participants (e.g., Desai, Dyck, and Zingales, 2007; Kerr, 2019; Balakrishnan et al. 2019), our findings provide timely policy implications that even private tax disclosure creates public information benefits.

Our study also contributes to the stream of literature that documents the economic consequences of mandated disclosure regulations. Whereas prior research focuses on public accounting regulations such as IFRS (e.g., Barth et al., 2018; Landsman et al., 2012; Tan et al., 2011), we provide new insight by documenting the benefits of private disclosure to the capital markets. By comparing CbCR adoptions across 33 countries, our study answers the call for more international evidence, "as disclosure and reporting regulation has become a global issue." (Leuz and Wysocki, 2016, p. 526-527).

\section{Institutional background and hypothesis development}

\subsection{Country-by-country reporting}

Combating base-eroding tax evasion has been a policy priority for governments worldwide. In 2013, the G20 finance ministers called on the OECD to develop an action plan that 
"provides countries with domestic and international instruments that will better align rights to tax with economic activity." (OECD, 2013). At the heart of this action plan is an effort to improve global tax transparency and information sharing. In 2015, the OECD finalized their recommendations for transfer pricing documentation and Country-by-Country reporting, which is referred to as Action Item 13. This action item requires multinationals to "provide all relevant governments with needed information on their global allocation of the income, economic activity, and taxes paid among countries according to a common template." (OECD, 2015, p. 9). ${ }^{2}$ Specifically, Action Item 13 develops a three-tiered approach to transfer pricing documentation, including the provision of a master file that provides high-level information of the MNE's global operation, a local file that requires detailed analysis for material intra-firm transactions for the local entity, and the $\mathrm{CbCR}$ for business operations in each tax jurisdiction where the MNE operates. The CbCR must include information on all constituent entities in each tax jurisdiction, their business activities, and the associated revenues, pre-tax profit (loss), income taxes, tangible assets, number of employees, stated capital and accumulated earnings (OECD, 2015). In most cases, the ultimate parent of the MNE group is responsible for submitting the $\mathrm{CbCR}$ to the tax authority in the jurisdiction of its tax residence. This report can then be shared, via information exchange agreements and treaties, with other jurisdictions where members of the MNE group operate. ${ }^{3}$

\footnotetext{
${ }^{2}$ There are two public CbCR initiatives that predate Action 13 of the OECD's Base Erosion and Profit Shifting initiatives. The first one is by the Extractive Industry Transparency Initiative (EITI) which requires companies in the extractive industry to report financial information by country, which is known as extraction payment disclosures. The second one is by the EU capital Requirement Directive IV, which focuses on the financial sector in the European Union by requiring public CbCR. Joshi et al. (2020) show that the public CbCR does not appear to influence tax avoidance among European financial firms.

${ }^{3}$ In the event that the ultimate parent entity cannot file $\mathrm{CbCR}$ with the home country, the multinational can designate a subsidiary as a surrogate entity for CbCR filing. The tax authority with which the surrogate entity files the CbCR will exchange this report with tax authorities in other jurisdictions. Additionally, a subsidiary country can request local filings of $\mathrm{CbCR}$ if it has an automatic information exchange agreement with the parent but not a competent authority agreement, or if there has been a failure in the exchanges between the parent country and the subsidiary country. In other words, a subsidiary country can only access $\mathrm{CbCR}$ if it has an automatic information exchange relationship with the parent country (Knobel and Cobham, 2016).
} 
The base erosive tax practices of multinational companies have received intense scrutiny from the public media and policymakers (e.g., Drucker, 2010; Senate Hearing 112-781, 2012; Senate Hearing 113-90, 2013). Tax avoidance schemes help MNEs to shift income away from high-tax countries, where substantive economic activities (i.e., asset investments and R\&D) take place, into low-tax or tax haven countries with little economic presence. Hanlon (2018) predicted the that the adoptions of CbCR can lead to an increase in the alignment between the firms' tax and economic activities through two types of responses: (1) substantiate existing tax avoidance by increasing economic activities in low-tax and tax haven countries and (2) report more taxable income in countries where economic activities take place. Similarly, Pascal Saint-Amans, the director of the Centre for Tax Policy and Administration at the OECD, anticipated that a large number of MNEs would likely to restructure their business organization as a result of $\mathrm{CbCR}$ (Houlder, 2014).

Recent research evidence supports that both types of corporate responses to CbCR are likely to exist (e.g., DeSimone and Olbert, 2019; Joshi, 2020). Focusing on the European setting, DeSimone and Olbert (2019) find that, as a result of CbCR, MNEs reduced ownership in tax haven subsidiaries and allocated more revenue, assets, and employees to subsidiaries in low-tax countries. Joshi (2020) finds that European firms subject to CbCR experienced an increase in both GAAP effective tax rate and cash effective tax rate in the post-implementation period, and there was some evidence of reduced tax-motivated income shifting among these firms. These findings indicate that firms might have reduced base erosive tax avoidance in response to $\mathrm{CbCR}$. Consistent with the research findings, in a recent survey by Deloitte on the OECD's Base Erosion and Profit Shifting initiative, over $94 \%$ of managers agree or strongly agree that corporate tax compliance burden will substantially increase, and nearly $55 \%$ of managers change the way of conducting tax planning for 
cross-border transactions (Deloitte, 2017). In summary, existing research on firm-level investment and tax avoidance behaviors suggest that MNEs have taken some actions to better align tax and economic activities following CbCR.

\subsection{Predictions on the information environment}

Over the past decade, financial analysts have increasingly provided disaggregated forecasts in addition to issuing aggregate earnings forecasts. Investors can use analysts' disaggregated forecasts to infer the forecasted tax expense and use this as an incremental information to value firms (Mauler, 2019). Similarly, prior literature finds that tax expense, incremental to book earnings, provides value relevant information for capital markets (Kerr, 2019; Mauler, 2019). Specifically, because managers pay and accrue more tax expense when profitability is high, both the current and deferred components of tax expense signal underlying firm profitability (Thomas and Zhang, 2014). However, to the extent that MNEs separate income from the locations where real operations occur, the reported tax expense is less representative of economic performance, which diminishes the information value of tax. Consistent with this prediction, researchers find that tax planning is associated with lower tax accrual quality (Choudhary et al., 2016), less accurate analysts' tax forecasts (Francis et al., 2019), and less value relevant tax surprise (Ayers et al., 2009). ${ }^{4}$ Thus, the misalignment between tax and economic activities likely weakens the quality of tax information for capital markets.

For capital markets, the misalignment issue further complicates the quality of earnings information. To shift the taxable income away from the location were economic activities occur, MNEs often rely on complex legal arrangements. For example, through a series of cross-border

\footnotetext{
${ }^{4}$ Consistent with the extant evidence, Kerr (2019) finds that the value relevance of tax surprise, incremental to earnings surprise, increases in countries with stronger tax enforcement.
} 
legal and tax arrangements, Apple managed to shift the economic ownership of intangible properties, together with the bulk of their offshore income, to subsidiaries in Ireland where income is taxed at special rates ranging between 0.05 percent and 2 percent. While accounting for less than one percent of Apple's R\&D and manufacturing activities, these Irish subsidiaries report 65.6 percent of cumulative worldwide pretax income from 2009 to 2012 (page 29, Levin and McCain 2013). The misalignment between tax and economic activities likely creates complexity and opacity for outside investors to understand the true source of MNEs' worldwide economic growth. Consistent with the prediction, Chen et al. (2018) show that tax motivated income shifting increases the information asymmetry between the firm and outside investors. Furthermore, there is strong empirical evidence that distortive tax practices weaken the earnings information environment. For example, Francis et al. (2019) find that tax planning measured by auditorprovided tax services is negatively associated with analysts' EPS forecast accuracy. Balakrishnan et al. (2019) show that tax aggressive firms have less accurate and more dispersed earnings forecasts.

As policymakers intend to use $\mathrm{CbCR}$ as a tool to increase tax transparency and to curb distortive tax practices, we first examine whether the misalignment between tax and economic activities among MNEs, as perceived by capital markets, decreases after $\mathrm{CbCR}$ adoptions. $\mathrm{CbCR}$ is a private disclosure to tax authorities, and it is unclear whether and how capital markets can benefit from the increased transparency. To examine this research question, we focus on the financial analysts because they are an important group of intermediaries who process the firm's financial information and provide forecasts and recommendations to other participants in the capital markets (Beyer et al., 2010; Bradshaw, 2012). Recent research suggests that analysts derive their tax expense forecasts by translating their assessment of a firm's economic performance into 
its tax estimates based on the tax law frameworks (Baik et al., 2016; Bratten et al., 2017; Mauler, 2019). Thus, the accuracy in analysts' understanding of how a firm's tax expense relates to its earnings offers a helpful benchmark for us to estimate the misalignment between the firm's tax and its economic activities. To the extent that $\mathrm{CbCR}$ deters firms from engaging in distortive tax practices, we expect that the misalignment between tax and economic activities, as perceived by financial analysts, to decrease after the policy adoptions.

Next, we examine how CbCR influences the quality of tax and earnings information for capital markets by reducing the misalignment between tax and economic activities. In particular, we focus on two major capital market participants: information intermediaries (e.g., financial analysts) and stock market investors. First, prior research suggests that both tax and earnings forecasts issued by analysts provide helpful information in evaluating firm performance (Bradshaw, 2012; Mauler, 2019), but these information is only valuable if it is accurate. Thus, the accuracy of analysts' forecasts is widely used in accounting literature to assess the quality of tax and earnings information (e.g., Balakrishnan et al., 2019). Second, prior research shows that both earnings surprise and tax surprise incremental to earnings provides value relevant information for investors (e.g., Hanlon et al., 2005; Kerr, 2019). We thus also use the value relevance of earnings surprise and incremental tax surprise to evaluate the quality of earnings and tax information. Taking both factors together, we predict that CbCR helps improve the tax information environment for capital markets to the extent that MNEs' tax expense will be driven more by income generated in regions and countries where firms have substantial economic activities. Similarly, the improved alignment reduces MNEs' needs for complex income shifting structures that make it more difficult to outsiders to understand the nature of MNEs' economic activities worldwide, which will in turn improve the earnings information environment for both analysts and investors. Specifically, we 
expect that the quality of tax and earnings information (e.g., analysts' forecast accuracy and the informativeness of tax and earnings) improves following $\mathrm{CbCR}$, and the information benefit should be greater for firms with larger misalignment before the policy implementation.

\section{Empirical design}

\subsection{CbCR Adoptions}

In Appendix A, we report a list of countries in our sample that mandatorily adopted CbCR starting from the fiscal year 2016. Different from prior CbCR research that focuses on Europe (De Simone and Olbert, 2019; Joshi, 2020), we incorporate other major global economies, such as, China, India, Japan, and the United States, to provide a more comprehensive view of the worldwide policy implications of $\mathrm{CbCR}$. We define the post-CbCR implementation period based on the fiscal year 2016 and onward. One unique feature of CbCR is the firm size-based threshold. Specifically, $\mathrm{CbCR}$ is mandatory for firms with consolidated revenue (in the preceding fiscal year) above a threshold specific to that country. For example, while most European countries require $\mathrm{CbCR}$ for firms with revenue above $€ 750$ million, which approximates to $\$ 815$ million U.S. dollars in 2016 , the United States designates its reporting threshold at $\$ 850$ million. To compare reporting thresholds across countries on the same currency basis, we obtain monthly exchange rates from the International Monetary Fund and convert local functional currencies to U.S. dollars using the average exchange rate in the month of CbCR implementation. We report the 2016 reporting thresholds in U.S. dollars equivalence in column (4). As presented in this table, the reporting thresholds vary from 554 million USD to 895 million USD, and such differences provide us with rich cross-country variations in identifying $\mathrm{CbCR}$ treatment firms. 


\subsection{Measuring misalignment}

We use a stylized model to illustrate how the misalignment between tax and economic activities is reflected in analysts' forecasts. We begin with a firm's realized tax expense denoted by T.E. Grubert (2012) suggests that MNEs' tax expense reflects a combination of economic activities and tax planning efforts that deviate from underlying economic performance. Motivated by this argument, we decompose T.E. into two components. The first component is the tax expense that corresponds to income-generating economic activities. Tax laws offer various incentives to stimulate certain corporate economic activities, such as depreciation deduction from purchases of capital assets and R\&D tax credits from R\&D investments. We define $X$ as income-generating economic activities and $\theta$ as the aggregate tax rate applicable to these economic activities. ${ }^{5}$ Thus, the product of $X$ and $\theta$ captures the portion of tax expense that is driven by economic activities. The second component, $\rho$, is the tax expense that deviates from firms' economic activities. This is a "black box" consisting of tax arrangements that cannot be observed by outsiders, such as confidential legal arrangements that MNEs set up to shift income and tax away from where valuecreating activities take place. We use $\rho$ to denote the extent of misalignment between the reported tax expense and the true amount of tax expense based on the firm's economic activities and express T.E. as:

$$
T E=X \theta+\rho .
$$

We next define analysts' forecasts of tax expense for the firm as $T E^{A F}$. Similarly, we decompose $T E^{A F}$ into two components. The first component is the tax expense forecast based on the firm's forecasted earnings. Tax laws can be complex and voluminous. Whereas analysts might have

\footnotetext{
5 To provide some intuition, suppose that a firm purchases an equipment that qualifies for full expensing in the first year and the firm is subject to a statutory tax rate of 30 percent, the applicable tax rate to the equipment is 30 percent.
} 
limited tax knowledge, they are well-equipped with the help of tax experts. Mauler (2019) suggests that analysts start by forecasting individual line items (e.g., sales and expense projection) leading to pre-tax income, and they rely on a tax expert to translate these line items to tax expense forecasts. Bratten et al. (2017) show that analysts overcome the complexity of tax laws and issue more accurate tax forecasts than management as the tax complexity increases. We thus define $X^{A F}$ as the forecast of income-generating economic activities and $\theta^{A F}$ as analysts' estimated tax rate applicable to these economic activities. The product of $X^{A F}$ and $\theta^{A F}$ captures analysts' estimate of tax expense driven by economic activities.

The second component of analysts' tax forecasts is one that is unrelated to the real economic performance of the firm. Like outsiders, analysts also lack public information to assess tax planning that deviates from economic activities. Whereas they may obtain information from private conversations with firm managers (e.g., firms' use of certain tax haven countries), we conjecture that the information acquisition process likely generates noise because analysts do not have a systematic approach to acquire and analyze all relevant information to forecast tax not substantiated by economic activities (Francis et al. 2019). We thus denote the noise term as $e^{A F}$, which has mean zero and variance of $\sigma_{e}^{2} \cdot{ }^{6} \mathrm{We}$ estimate $T E^{A F}$ using the equation below:

$$
T E^{A F}=X^{A F} \times \theta^{A F}+e^{A F}
$$

By subtracting equation (2) from equation (1), we estimate analysts' tax forecast error (TFE) below,

$$
T F E=T E-T E^{A F}=X \times \theta-X^{A F} \times \theta^{A F}+\rho-e^{A F} .
$$

By rearranging the terms above, we have the following equation:

\footnotetext{
${ }^{6} \mathrm{We}$ follow the convention of Hanlon et al. (2008) in assuming the random distribution of the noise term.
} 


$$
T F E=T E-T E^{A F}=\theta \times\left(X-X^{A F}\right)+\left(\theta^{A F}-\theta\right) \times X^{A F}+\rho_{t}-e^{A F}
$$

By taking expected value for each term in equation (4) and rearranging them, we have,

$$
E(\rho)=E(T F E)-\theta \times\left(E(X)-E\left(X^{A F}\right)\right)-\left(\theta^{A F}-\theta\right) \times E\left(X^{A F}\right)
$$

The stylized model above, albeit simple, offers a theoretical way to express the expected value of tax misalignment $(E(\rho))$ as a function of analysts' tax forecast error (TFE), the difference between realized and analysts' forecast of economic activities $\left(X-X^{A F}\right)$, and analysts' forecast of economic activities $\left(X^{A F}\right)$. To operationalize equation (4) in an empirical framework, we estimate the following regression:

$$
\text { TAXEXP_AFError }{ }_{i j t}=\beta_{1} \text { PRE_AFError }{ }_{i j t}+\beta_{2} P R E \_A F_{i j t}+\tau_{i j t .}
$$

We use $i, j, t$ to separately denote firm, country, and year. The dependent variable (TAXEXP_AFError ${ }_{i j t}$ ) is analysts' tax forecast error, measured by the absolute difference between the mean of analysts' implicit tax expense forecasts immediately before the end of the fiscal year and the $\mathrm{I} / \mathrm{B} / \mathrm{E} / \mathrm{S}$ implied annual tax expense for that fiscal year, scaled by the price at the end of the previous year. ${ }^{7}$ Following Bratten et al. (2017), we calculate analysts' implicit tax forecasts by subtracting after-tax earnings forecasts from pre-tax earnings forecasts and calculate the firm's implied tax expense by subtracting I/B/E/S actual after-tax earnings from actual pre-tax earnings. To capture analysts' forecast of economic activities $\left(X^{A F}\right)$, we use analysts' forecast of pre-tax earnings $\left(P R E_{-} A F_{i j t}\right)$ because earnings summarize the observed outcome of economic activities impacting income and provide a more comprehensive view of the net impact of economic activities relative to selected activities reported by analysts (e.g., sales forecasts). To empirically proxy $(X$ -

\footnotetext{
${ }^{7}$ To calculate the implied tax expense, we require the forecasts of pre-tax and net-of-tax earnings to be issued by the same analyst on the same day. The stock price at the end of the previous year is adjusted for any stock split that occurred during the prior year.
} 
$X^{A F}$ ), we use PRE_AFError $i j$, analysts' pre-tax earnings forecast error, measured by the absolute difference between the mean of analysts' pre-tax earnings forecasts immediately before the end of the fiscal year and the $\mathrm{I} / \mathrm{B} / \mathrm{E} / \mathrm{S}$ pre-tax earnings for that fiscal year, scaled by the price at the end of the previous year. See Appendix A for detailed variable definitions. By estimating Equation (6) by country, we use the regression residuals to capture unexplained tax forecast errors. ${ }^{8}$ We then use the absolute value of the residuals to proxy for the extent of misalignment perceived by capital markets, denoted by Tax_Misalignment.

\subsection{Changes of misalignment following $C b C R$}

To examine how $\mathrm{CbCR}$ influences firms' misalignment, we begin with a difference-indifference design explained below:

$$
\text { Tax_Misalignment } t_{j i t}=\gamma_{0}+\gamma_{1} \text { Treat }_{i j t} * C b C R_{t}+\sum \gamma_{k} \text { Control }_{k}+\sum F E_{d}+\varepsilon_{i j t .}
$$

The dependent variable is the firm's misalignment between tax and economic activities measured by the absolute value of residuals from equation (6). Treat equals one if the consolidated revenue of firm $i$ in the preceding year meets the reporting threshold of country $j$ from 2016 to 2019 and zero otherwise. ${ }^{9} \mathrm{CbCR}$ equals one for the fiscal year 2016 and the following years and zero otherwise. To the extent that $\mathrm{CbCR}$ helps reduce the tax misalignment among firms, we expect the coefficient on Treat $* C b C R$ to be negative $\left(\gamma_{1}<0\right)$. Similar to prior research examining forecast accuracy in an international sample (Byard et al., 2011; Tan et al., 2011), we include a vector of firm-level control variables, including annual sales growth (SalesGrowth), share turnover

\footnotetext{
${ }^{8}$ We estimate equation (4) by country to control for country-level heterogeneity. We require each regression to have at least 40 observations.

${ }^{9}$ Treat identifies firms that meet the reporting threshold in any year between 2016 and 2019 as being subject to CbCR treatment for the whole sample period. To construct a true difference-in-difference design, we follow Joshi (2020) by comparing firms above and below the reporting threshold and before and after the $\mathrm{CbCR}$ implementation.
} 
(ShareTurnover), market value (MarketValue), leverage (Leverage). We also control for overall information environment using the number of analysts following the firm during the year (AnalystFollowing) and the standard deviation of analysts' pre-tax earnings forecasts during the year before the earnings announcement (PRE_AFDisp).${ }^{10}$ To control for heterogeneity at the firm and country-year level, we use firm fixed effects and country-year fixed effects. We cluster standard errors by country to control for within-country correlations. ${ }^{11}$

To strengthen the robustness of the test for tax misalignment, we further exploit the country-specific size thresholds for $\mathrm{CbCR}$ in a regression discontinuity design. Specifically, we test for the causal effects of CbCR by comparing Tax_Misalignment ${ }_{i j t}$ of firms right above the threshold to those just below it. Prior $\mathrm{CbCR}$ research supports using the local randomized assignment of the reporting threshold, as firms are unlikely to manage their revenue to fall below the threshold (DeSimone and Olbert, 2019; Joshi 2020). We thus create a continuous running variable based on consolidated revenue from the preceding fiscal year for firm $i$ in country $j$ and year $t$ subtracted by the country-specific reporting threshold. ${ }^{12}$ Using different bandwidths to compare firms right above to those right below the zero cutoffs of the running variable, we use flexible nonparametric functional forms to test the impact of CbCR on Tax_Misalignment. To control for omitted factors, we include control variables from equation (8) as covariates in the regression discontinuity design. Additionally, we include country and year indicator variables as covariates to control for unobserved country and year factors. Similar to prior regression

\footnotetext{
${ }^{10}$ We require at least two analysts following a firm-year to calculate the standard deviation of analyst pretax earnings forecasts.

${ }^{11}$ Our main results are robust to clustering by country-year.

${ }^{12}$ For the purpose of the regression discontinuity tests, we follow Joshi (2020) and allow the running variable and treatment firm to vary by year.
} 
discontinuity research (e.g., Chen et al., 2019; Khan et al., 2017), we use local linear regressions with a triangle kernel and report bias-corrected estimates.

\subsection{Changes of tax and earnings information environment following $C b C R$}

To test how CbCR influences the tax information environment, we begin with examining whether analysts' tax forecast accuracy improves after $\mathrm{CbCR}$ adoptions and whether this improvement is more pronounced for firms with more misalignment before the policy implementation. Specifically, we replace the dependent variable in equation (7) with analysts' tax forecast error (TAXEXP_AFError) as previously defined, and estimate the regression separately for observations with low and high pre-CbCR misalignment. We define a firm with high (low) pre-CbCR misalignment if its average value of Tax_Misalignment before CbCR adoption (i.e., when $C b C R=0$ ) is above (below) the sample median. Consistent with CbCR reducing tax forecast error by mitigating the misalignment, we expect that the coefficient on $\operatorname{Treat}{ }^{*} C b C R$ to be negative and the coefficient is more negative in the subsample with high pre-CbCR misalignment than in the subsample with low pre-CbCR misalignment.

Next, we follow prior literature and use the value relevance of tax surprise to test whether investors experience an improvement in the tax information environment of the firm following CbCR. Following the early evidence of an association between total tax expense and contemporaneous stock return (Ohlson and Penman, 1992), recent research uses quarterly (or annually) differenced tax expense to proxy for tax surprise and consistently supports the value relevance of tax expense incremental to book earnings (Hanlon et al., 2005; Kerr, 2019; Thomas and Zhang, 2011). We thus modify the regression of Kerr (2019) to accommodate a difference-indifference design as below: 


$$
\begin{aligned}
& \text { BHR }_{i j t}=\alpha_{0}+\alpha_{1} \text { UnTaxSurp }_{i j t}+\alpha_{2} \text { Treat }_{i j t} * \operatorname{CbCR}_{t} * \operatorname{UnTaxSurp}_{i j t} \\
& +\alpha_{3} \text { Treat }_{i j t} * U n \text { TaxSurp }_{i j t}+\alpha_{4} \text { CbCR }_{t} * U_{n \text { TaxSurp }} \text { Tijt }+\alpha_{5} \text { Treat }_{i j t} * C b C R_{t} \\
& +\sum \alpha_{k} \text { Control }_{k}+\sum F E_{d}+\varepsilon_{i j t} \text {. }
\end{aligned}
$$

The dependent variable $\left(B H R_{i j t}\right)$ is cumulative buy-and-hold returns for firm $i$ over a 12month period, starting from the first day of the fourth month of the fiscal year $t$ and ending by the third month of the following fiscal year. ${ }^{13}$ Unexplained tax surprise (UnTaxSurp) is the residual of regressing tax surprise on earnings surprise, and we use annually differenced tax expense (pre-tax earnings) scaled by lagged total assets to measure tax (earnings) surprise. ${ }^{14}$ A positive coefficient on UnTaxSurp suggests that investors find incremental tax surprise, relative to earnings surprise, informative $\left(\beta_{1}>0\right)$ (Kerr, 2019). Treat and $C b C R$ are defined previously. By interacting Treat*CbCR with UnTaxSurp, we examine how the value relevance of incremental tax surprise for treatment firms changes following CbCR. A positive coefficient on Treat ${ }^{*} C b C R^{*}$ UnTaxSurp suggests that the incremental tax surprise becomes more informative for treatment firms following CbCR. ${ }^{15}$ Similar to the test above, we partition the sample into observations with low and high pre-CbCR misalignment. We expect that CbCR helps increase tax value relevance when firms have more misalignment issues before the policy implementation. Therefore, we predict that the coefficient on $\operatorname{Treat}^{*} \mathrm{CbCR} *$ UnTaxSurp to be more positive in the high pre-CbCR misalignment subsample than in the low-misalignment subsample. For completeness, we include other interaction terms, including Treat*UnTaxSurp, $C b C R^{*}$ UnTaxSurp, and Treat ${ }^{*} C b C R .{ }^{16}$ We do not

\footnotetext{
${ }^{13}$ We calculate 12-month returns by accumulating daily stock returns from CRPS and Security Daily. We require the firm to have at least 250 non-missing daily returns during the year to avoid outliers with sparse stock return information.

${ }^{14}$ Specifically, we regress tax surprise on earnings surprise by country to control for country-level heterogeneity. We require each regression to have at least 40 observations. Our results remain similar when we estimate each regression within a country-year group.

15 To alleviate the concern of coefficient bias from a two-stage regression, we also run a single equation by including both tax surprise and earnings surprise, which are separately interacted with Treat, $C b C R$, and $T r e a t^{*} C b C R$. We find consistent results of more informative incremental tax surprise following $\mathrm{CbCR}$ as the coefficient on Treat ${ }^{*} C b C R^{*}$ TaxSurp is significantly positive at one percent statistical level.

${ }^{16}$ The main effects of $C b C R$ and Treat are absorbed by firm fixed effects and country-year-month fixed effects.
} 
offer predictions for these coefficients. Following Kerr (2019), we control for market value (MarketValue), book-to-market ratio (B2M), and 12-month cumulative stock returns from the preceding fiscal year $\left(\right.$ Return $\left._{t-1}\right)$. We consistently include firm- and country-year fixed effects and cluster standard errors by country.

In a similar approach to testing the tax information environment, we examine the changes in earnings information environment following CbCR using analysts' earnings forecast accuracy and earnings value relevance. To test for forecast accuracy, we replace the dependent variable in equation (7) separately with analysts' pre-tax earnings forecast error (PRE_AFError) and their after-tax earnings forecast error (NET_AFError). By estimating the regression for observations with low and high pre-CbCR misalignment, we expect that the coefficient on $T r e a t^{*} C b C R$ to be negative and the coefficient is more negative in the subsample with high pre-CbCR misalignment than in the subsample with low pre-CbCR misalignment. This is consistent with our prediction that $\mathrm{CbCR}$ helps reduce earnings forecast error and improve forecast quality by mitigating misalignment.

To test earnings value relevance, we replace UnTaxSurp in equation (8) with earnings surprise (EarnSurp), measured by the change in pre-tax earnings from $t$ - 1 to $t$ scaled by assets at the end of year $t-1$. We predict a positive coefficient on Treat ${ }^{*} C b C R^{*}$ EarnSurp to the extent that earnings surprise becomes more informative following CbCR. By estimating the regression for observations with low and high pre-CbCR misalignment, we expect the coefficient on Treat $* C b C R^{*}$ EarnSurp to be more positive in the high pre-CbCR misalignment subsample than in the low-misalignment subsample. Our prediction is consistent with $\mathrm{CbCR}$ improving earnings informativeness, and the effect is greater when firms have more misalignment before the policy implementation. 


\section{Empirical results}

\section{Sample Selection and Empirical results}

\subsection{Sample Selection}

Our sample period ends in 2019, which is the last year with available financial information. Because countries adopt CbCR as early as 2016, to balance the number of years in pre- and postCbCR adoption, our sample period begins in 2012 (i.e., four years before 2016). We construct our sample from the intersection of Compustat NA, Compustat Global, and I/B/E/S U.S. and international files. The combination of these data files gives a broad coverage of firms in developed and developing economies. We take several steps to refine the sample for $\mathrm{CbCR}$ tests by requiring that 1) firms have the same country for headquarters and incorporations; ${ }^{17}$ 2) each country has at least 100 firm-year observations; 3 ) each firm has at least one year of observation in the post CbCR-adoption period. These additional steps eliminate outliers and allow us to focus on the observations with sufficient variations in the post-implementation period. The initial sample has 82,129 firm-year observations.

To test tax misalignment and analyst forecast accuracy, we require analyst forecasts to include both pre-tax and after-tax income in order to calculate the implied tax expense forecasts. After excluding observations without sufficient data to calculate control variables in equation (7), we have 40,123 observations for the analyst forecast accuracy subsample. To test tax misalignment and the value relevance of tax surprise and earnings surprise, we merge the initial sample with

\footnotetext{
17 The BEPS Action Item 13 states that a CbCR should be filed by the Ultimate Parent Entity (UPE) of an MNE group with the tax authority in its jurisdiction of residence (OECD, 2015). While headquarters and incorporations generally represent UPE jurisdictions, it is unclear how firms decide UPEs when their headquarters locate in a different country from the state of incorporation. We thus remove these observations when the locations of UPEs are not clear.
} 
Security Daily (North America and International files) to obtain stock return information. After excluding observations without sufficient data to calculate the regression variables in equation (8), we have 54,205 observations for the value relevance subsample.

Based on the two subsamples defined in Table 1, Table 2 reports their distribution by country. In total, our samples include firms from 41 countries, including those in Africa, America, Australia, Asia, and Europe. A sizable portion of our samples (53.10\%-56.04\%) locates in large economies: the United States, China, and Japan. It is also worth noting that our sample extends beyond prior studies that focus on the adoption of CbCR in Europe (e.g., De Simone and Olbert, 2019; Joshi, 2020). The estimated misalignment between tax and economic activities exhibit a large variation across countries. For example, the average Tax_misalignment of Columbia, Japan, and Korea is less than 0.01, while that of Argentina and Greece is larger than 2.10. In untabulated results, we separately examine Tax_misalignment for companies well known for their income shifting practices. As an example, the average Tax_misalignment for Apple in the pre-CbCR (postCbCR) period is 0.09 (0.03), which declined by $67 \%$ following CbCR adoption in the U.S. This anecdotal evidence supports the effectiveness of $\mathrm{CbCR}$ in aligning tax with economic activities.

\subsection{Summary Statistics}

Table 3 reports the descriptive statistics for the treatment and control groups, defined as firm-year that (do not) meet the $\mathrm{CbCR}$ revenue threshold in that country. Compared to the control group, firms in the treatment group are larger, both in terms of total revenue and market capitalization, which is consistent with the size threshold of CbCR. Focusing on Panel A, treatment firms appear to have lower sales growth (5.0\% versus $8.7 \%)$ but are more leveraged ( $20.4 \%$ versus $14.4 \%)$ than the control firms on average. 


\section{3. $C b C R$ and Tax Misalignment}

To estimate the extent of misalignment between tax and economic activities, Table 4 reports the results from the regression of analysts' tax forecast error on analysts' earnings forecast error and analysts' earnings forecasts based on equation (6). Panel A presents country-level regressions based on the analyst forecast accuracy subsample. Consistent with our expectation that analysts derive their tax forecasts from earnings forecasts, analysts' tax forecast error is positively related to their pre-tax earnings forecast error (the mean of coefficients $\beta_{1}$ is 0.253 ). We also find that analysts' tax forecast error is positively related to their pre-tax earnings forecast (the mean of coefficients $\beta_{2}$ is 22.150). Recall that from our theoretical modeling, equation (4) shows that $\beta_{2}$ conceptually captures the difference between analysts' estimated tax rate applicable to incomegenerating economic activities $\left(\theta^{A F}\right)$ and the firm's actual tax rate applicable to these economic activities $(\theta)$. The positive average value of $\beta_{2}$ means that analysts' estimated tax rates on average are higher than the firm's actual tax rates, suggesting that analysts tend to give more conservative tax estimates and/or firms engage in more aggressive tax planning than what outsiders would expect. Adjusted R-squares indicate that our specification provides reasonable explanation power (the mean adjusted $\mathrm{R}^{2}$ is 0.288 ). We find similar estimates in Panel B based on the value relevance subsample. Based on these country-level regressions, we use the absolute value of these residuals to capture misalignment between tax and economic activities (Tax_misalignment).

In Table 5 Panel A, we examine whether CbCR mitigates tax misalignment using a difference-in-difference design. In column (1), we present the regression results of equation (7) where the absolute value of the residual terms from Table 4 is the dependent variable (Tax_misalignment). Our primary variable of interest is the two-way interaction term, Treat ${ }^{*} C b C R$, which captures the change in tax misalignment for the treated firms after CbCR adoption. The 
estimated coefficient on the interaction term is negative and statistically significant $\left(\gamma_{1}=-0.068, p\right.$ $=0.011$, consistent with our expectation that $\mathrm{CbCR}$ adoptions reduce analysts' perception of the firm's misalignment between tax and economic activities. The results in column (1) are based on a two-stage approach in which we use the absolute value of residuals from equation (6) as the dependent variable in the second-stage equation (7). Prior research suggests that this two-stage procedure can generate biased coefficients and standard errors, and it is important to show the sensitivity of results to a single equation (Chen, Hribar, and Melessa, 2017). In Appendix C, we discuss how the single equation approach can be performed based on transformed analysts' tax forecast error (TAXEXP_AFError $\left.{ }^{T}\right)$, pre-tax earnings forecast error $\left(P R E \_A F E r r o r^{T}\right)$, and pretax earnings forecasts $\left(P R E_{-} A F^{T}\right)$ to account for the absolute value of Tax_misalignment in combining equations (6) and (7) together. ${ }^{18}$ In column (2), we report the results of estimating the single equation. After controlling for the transformed values of pre-tax earnings forecast error and pre-tax earnings forecasts, $\operatorname{Treat}^{*} \mathrm{CbCR}$ captures the incremental change in abnormal analysts' tax forecast error (e.g., tax misalignment) attributable to CbCR. The coefficient on Treat ${ }^{*} C b C R$ remains significantly negative $(-0.059, \mathrm{p}=0.003)$, and the size of the coefficient based on the single equation is similar to that based on the two-stage equations in column (1). Overall, we find robust results that $\mathrm{CbCR}$ mitigates misalignment using a difference-in-difference design.

We next exploit the country-specific size thresholds for CbCR to test tax misalignment in a regression discontinuity design (RDD). RDD relies on the assumption that firms are not able to manipulate the reporting threshold for CbCR. Figure 1a provides the density plot of firms' consolidated revenue, and the distribution of firms around the reporting threshold is relatively

\footnotetext{
${ }^{18}$ To be consistent with estimating Tax_Misalignment using Equation (6) based on country-level portfolios, we follow Chen et al. (2017) and interact each transformed independent variable from Equation (6) with country indicator variables in the single-equation.
} 
smooth and continuous. Furthermore, the significant overlap of the 95 percent confidence intervals around both sides of the cutoff suggests that firms are unlikely to manipulate this threshold to avoid reporting, which is consistent with the evidence from prior CbCR research (De Simone and Olbert, 2019; Joshi, 2020).

Figures $1 \mathrm{~b}-\mathrm{d}$ provide regression discontinuity plots of Tax_Misalignment in the preadoption period for three different bandwidths around the reporting threshold (100M, 150M, and 200M USD). We use the fourth-order polynomial fit to approximate the population conditional expectation functions for control and treatment groups. Figures 1e-g report similar plots of Tax_Misalignment in the post-adoption period. Figures $1 \mathrm{~b}$-d show little to no discontinuity in Tax_Misalignment around the reporting threshold in the pre-adoption period (with the exception of a seemingly positive discontinuity under the bandwidth 100M in Figure 1b). In contrast, the post-implementation graphs in Figures 1e-g exhibit a negative discontinuity in Tax_Misalignment at the reporting threshold, providing visual evidence of a reduction in misalignment between tax and economic activities in firms subject to $\mathrm{CbCR}$ following the policy implementation.

In Panel B of Table 6, we perform nonparametric regression discontinuity tests using a local linear regression model and report the bias-corrected estimates for pre- and post-CbCR implementation periods separately. We augment the three bandwidths above with the optimal bandwidth following the algorithm of Calonico et al. (2020). In the pre-CbCR period, Panel B1 shows that there is no significant discontinuity in Tax_Misalignment at the CbCR reporting threshold across all four columns. Panel B2 reports regression discontinuity results for the postCbCR implementation period. Though the optimal bandwidth generates a negative but insignificant estimate $(-0.089, \mathrm{p}>0.10)$, we find negative and significant estimates at the five percent level, using the $\$ 100$ million (-0.388) and $\$ 150$ million (-0.309) bandwidths. Overall, our 
results from regression discontinuity are consistent with those from the difference-in-difference analysis in that CbCR helps mitigate misalignment.

\subsection{CbCR and Tax Information Environment}

To test how CbCR influences the tax information environment by mitigating tax misalignment, we begin with the examination of analysts' tax forecast accuracy in Table 6. By replacing the dependent variable in equation (7) with analysts' tax forecast error, we report regression results for the analyst forecast accuracy sample in column (1). Furthermore, to test the importance of misalignment in improving analysts' tax forecast accuracy, we partition the sample based on the median value of firm-specific average of Tax_Misalignment before CbCR in columns (2) and (3) and expect greater tax information benefits in the high pre-CbCR misalignment subsample than in the low pre-CbCR misalignment subsample. ${ }^{19}$

Consistent with our prediction, we find that the coefficient on $T r e a t^{*} C b C R$ is negative and significant in column (1) $(-0.001, \mathrm{p}=0.098)$. The coefficient remains significantly negative in the subsample with high pre-CbCR misalignment in column (3) $(-0.001, p=0.094)$, but it becomes insignificant and has a magnitude close to zero in the subsample with low pre-CbCR misalignment in column (2) $(-0.000, \mathrm{p}=0.997)$. However, the difference in these coefficients is not significant based on the two-tailed z-test $(\mathrm{p}=0.117)$. Our evidence suggests that CbCR plays an important (insignificant) role in improving analysts' tax forecast accuracy when pre-CbCR misalignment is high (low), generating better analysts' tax forecast accuracy overall.

\footnotetext{
${ }^{19}$ Clogg, Petkova, and Haritou (1995, page 1276) developed the Z-test to compare common coefficients across subsamples. This is commonly used in accounting literature, especially with high dimensional fixed effects as in our case (e.g., Bhojraj et al. 2017). To facilitate interpretation, we translate z-statistic to the equivalent p-value and report the significance level in brackets.
} 
In Table 7, we continue to examine the tax information environment by testing the value relevance of incremental tax surprise for investors based on equation (8). We similarly report regression results for the value relevance sample in column (1) and report cross-sectional results based on low- and high-misalignment in columns (2) and (3). Our primary variable of interest is UnTaxSurp $*$ Treat ${ }^{*} C b C R$, which captures the change in the value relevance of incremental tax surprise for $\mathrm{CbCR}$ firms following the policy implementation. The estimated coefficient on the interaction term is positive and statistically significant $\left(\alpha_{2}=1.381, \mathrm{p}=0.006\right)$, supporting our expectation that $\mathrm{CbCR}$ adoption helps improve the informativeness of incremental tax surprise, relative to earnings, for capital market investors. For control variables, similar to Kerr (2019), we find that lagged stock return (Return) is negatively associated with stock return.

In the cross-sectional tests reported in columns (2) and (3), we find that the coefficient on UnTaxSurp $*$ Treat $* C b C R$ is positive and statistically significant for the high-misalignment subsample $\left(\alpha_{2}=2.090, \mathrm{p}\right.$-value $\left.=0.002\right)$, but is not significant for the low-misalignment subsample $\left(\alpha_{2}=0.175, \mathrm{p}-\mathrm{value}=0.781\right)$. The difference between these two coefficient estimates is significant at the one percent level $(\mathrm{p}=0.000)$. These results support our prediction that $\mathrm{CbCR}$ plays a more important role in increasing tax value relevance when firms have more misalignment before the policy implementation. Taking Tables 6 and 7 together, we find that $\mathrm{CbCR}$ improves the tax information environment by mitigating misalignment between tax and economic activities.

\section{5. $C b C R$ and Earnings Information Environment}

In Table 8, we examine how CbCR influences the earnings information environment by mitigating misalignment. Similar to the tests for the tax information environment, we begin with analysts' earnings forecast accuracy by replacing the dependent variable in equation (7) with

analysts' pre-tax earnings forecast error (PRE_AFError) and report estimation results in columns 
(1)-(3). We find that the coefficient on $\operatorname{Treat}^{*} C b C R$ is negative and significant $(-0.003, \mathrm{p}=0.000)$ in column (1). Furthermore, that the coefficient is negative and significant in the highmisalignment subsample in column (3) $(-0.005, \mathrm{p}=0.000)$ and is slightly negative in the lowmisalignment subsample in column (2) $(-0.001, \mathrm{p}=0.050)$. The difference in these coefficients is significant at the one percent level. We document a similar finding using the after-tax earnings forecast error (NET_AFError) as the dependent variable in columns (4)-(6). Together, Table 8 results suggest that $\mathrm{CbCR}$ helps reduce analysts' earnings forecast error, and the effect is more pronounced when firms have more misalignment between tax and economic activities before the policy implementation.

We also examine the earnings information environment by testing the value relevance of earnings surprise for investors in Table 9. Specifically, we replace tax surprise (UnTaxSurp) in equation (8) with earnings surprise (EarnSurp) and examine whether CbCR helps improve earnings informativeness. Our primary variable of interest is EarnSurp ${ }^{*}$ Treat ${ }^{*} C b C R$, which captures the change in the value relevance of earnings surprise for $\mathrm{CbCR}$ firms following the policy implementation. In column (1), we find that the coefficient on EarnSurp $*$ Treat $* C b C R$ is positive (0.346) but not significant at the conventional levels based on the value relevance sample. Nevertheless, the coefficient becomes positive and significant $(0.655, \mathrm{p}=0.028)$ based on the high-misalignment subsample in column (3), and negative and significant $(-0.452, \mathrm{p}=0.055)$ in the low-misalignment subsample in column (2). The difference in these coefficients is statistically significant $(\mathrm{p}=0.000)$. Consistent with Table 8 , this evidence demonstrates that the effect of $\mathrm{CbCR}$ on earnings informativeness is more pronounced for firms with high levels of misalignment before the policy implementation.

\section{Conclusion}


We examine whether $\mathrm{CbCR}$ helps improve the tax and earnings information environment for capital markets to the extent that $\mathrm{CbCR}$ helps reduce the misalignment between tax and economic activities. Using a novel approach to estimate the firms' misalignment through financial analysts' forecasts, we find that the tax misalignment decreases following CbCR. Such evidence is consistent with the overall policy objective of the OECD's BEPS project. We further document consistent evidence that $\mathrm{CbCR}$ helps improve the tax and earnings information environment of the firm. The adoptions of $\mathrm{CbCR}$ have led to an improvement in analysts' tax (earnings) forecast accuracy and the value relevance of tax (earnings) to investors, though the evidence is weaker for the value relevance of earnings. More importantly, we find that the improvement in firms' information qualities varies with the level of misalignment prior to $\mathrm{CbCR}$. The improvements in earnings forecast accuracy and those in the informativeness of tax and earnings are more pronounced for firms with high levels of misalignment before the policy implementation. Overall, our evidence suggests that $\mathrm{CbCR}$ helps improve MNEs' external information environment by mitigating misalignment between tax and economic activities.

Our study contributes to the body of recent research that examines the economic consequences of mandated private CbCR (e.g., De Simone and Olbert, 2019; Joshi, 2020) by documenting its positive capital market externalities. Our findings provide timely evidence for firms, investors, governments, and other stakeholders, as they try to assess the immediate policy impacts of CbCR. Even though members of the public are not the intended information users of these private tax disclosures, we show that $\mathrm{CbCR}$ helps improve earnings and tax information environment and ultimately benefits capital market participants. As tax transparency has become a global policy priority, our study contributes to a new stream of research that explores how private disclosure regulation can generate positive externalities to public information users. 


\section{References}

Ayers, B.C., Jiang, J., Laplante, S.K., 2009. Taxable income as a performance measure: The effects of tax planning and earnings quality. Contemporary accounting research 26 (1) 15-54.

Baik, B., Kim, K., Morton, R., Roh, Y., 2016. Analysts' pre-tax income forecasts and the tax expense anomaly. Review of Accounting Studies 21 (2) 559-595.

Balakrishnan, K., Blouin, J.L., Guay, W.R., 2019. Tax Aggressiveness and Corporate Transparency. The Accounting Review 94 (1) 45-69.

Barth, M.E., Landsman, W.R., Lang, M.H., Williams, C.D., 2018. Effects on Comparability and Capital Market Benefits of Voluntary IFRS Adoption. Journal of Financial Reporting 3 (1) $1-22$.

Beyer, A., Cohen, D.A., Lys, T.Z., Walther, B.R., 2010. The Financial Reporting Environment: Review of The Recent Literature. Journal of Accounting and Economics 50 (2-3) 296-343.

Botosan, C.A., Stanford, M., 2005. Managers' Motives to Withhold Segment Disclosures and the Effect Of SFAS No. 131 on Analysts' Information Environment. The Accounting Review 80 (3) $751-772$.

Bradshaw, M.T., 2012. Discussion of “Analysts' industry expertise”. Journal of Accounting and Economics 54 (2-3) 121-131.

Bratten, B., Gleason, C.A., Larocque, S.A., Mills, L.F., 2017. Forecasting Taxes: New Evidence From Analysts. The Accounting Review 92 (3) 1-29.

Byard, D., Li, Y., Yu, Y., 2011. The Effect of Mandatory IFRS Adoption on Financial Analysts' Information Environment. Journal of Accounting Research 49 (1) 69-96.

Calonico, S., Cattaneo, M.D., Farrell, M.H., 2020. Optimal Bandwidth Choice for Robust BiasCorrected Inference in Regression Discontinuity Designs. The Econometrics Journal 23 (2) $192-210$.

Chen, C.-W., Hepfer, B.F., Quinn, P.J., Wilson, R.J., 2018a. The Effect of Tax-Motivated Income Shifting on Information Asymmetry. Review of Accounting Studies 23 (3) 958-1004.

Chen, S., Huang, Y., Li, N., Shevlin, T., 2019. How does quasi-indexer ownership affect corporate tax planning? Journal of Accounting and Economics 67 (2-3) 278-296.

Chen, W., Hribar, P., Melessa, S., 2018b. Incorrect Inferences When Using Residuals as Dependent Variables. Journal of Accounting Research 56 (3) 751-796.

Choudhary, P., Koester, A., Shevlin, T., 2016. Measuring Income Tax Accrual Quality. Review of Accounting Studies 21 (1) 89-139. 
De Franco, G., Kothari, S.P., Verdi, R.S., 2011. The Benefits of Financial Statement Comparability. Journal of Accounting Research 49 (4) 895-931.

De Simone, L., Olbert, M., 2019. Real Effects of Private Country-by-Country Disclosure. Working paper. Stanford Graduate School of Business and University of Mannheim - Business School.

Deloitte, 2017. The Global Tax Reset - Summary Results of the 2017 Annual Multinational Survey.

Drucker, J., 2010. U.S. Companies Dodge $\$ 60$ billion in Taxes With Global Odyssey.

Dyreng, S.D., Hoopes, J.L., Langetieg, P., Wilde, J.H., 2020. Strategic subsidiary disclosure. Journal of Accounting Research 58 (3) 643-692.

Dyreng, S.D., Hoopes, J.L., Wilde, J.H., 2016. Public Pressure and Corporate Tax Behavior. Journal of Accounting Research In-Press.

Francis, J.R., Neuman, S.S., Newton, N.J., 2019. Does Tax Planning Affect Analysts' Forecast Accuracy? Contemporary Accounting Research 36 (4) 2663-2694.

Grubert, H., 2012. Foreign Taxes and the Growing Share of US Multinational Company Income Abroad: Profits, Not Sales, Are Being Globalized. National Tax Journal 65 (2) 247-282.

Hanlon, M., 2018. Country-By-Country Reporting and The International Allocation of Taxing Rights. International Bureau of Fiscal Documentation (IBFD).

Hanlon, M., Kelley Laplante, S., Shevlin, T., 2005. Evidence For The Possible Information Loss of Conforming Book Income and Taxable Income. The Journal of Law and Economics 48 (2) $407-442$.

Hanlon, M., Maydew, E.L., Shevlin, T., 2008. An Unintended Consequence of Book-Tax Conformity: A Loss of Earnings Informativeness. Journal of Accounting and Economics $46(2-3)$ 294-311.

Hoopes, J.L., Robinson, L., Slemrod, J., 2018. Public tax-return disclosure. Journal of Accounting and Economics 66 (1) 142-162.

Houlder, V., 2014. OECD Denies New Rules Are Biased Against Low-Tax Countries. Financial Times. Retrieved from https://www.ft.com/content/5f06a9f8-ba80-11e3-a905$\underline{00144 \mathrm{feabdc} 0}$

Joshi, P., 2020. Does Private Country-by-Country Reporting Deter Tax Avoidance and Income Shifting? Evidence from BEPS Action Item 13. Journal of Accounting Research 58 (2) 333-381.

Joshi, P., Outslay, E., Persson, A.V., 2020. Does Public Country-by-Country Reporting Deter Tax Avoidance and Income Shifting? Evidence from the European Banking Industry. Contemporary Accounting Research Forthcoming. 
Kerr, J.N., 2019. The Value Relevance of Taxes: International Evidence on The Proxy For Profitability Role Of Tax Surprise. Journal of Accounting and Economics 67 (2-3) 297305.

Khan, M., Srinivasan, S., Tan, L., 2017. Institutional Ownership and Corporate Tax Avoidance: New Evidence. The Accounting Review 92 (2) 101-122.

Knobel, A., Cobham, A., 2016. Country-by-Country Reporting: How Restricted Access Exacerbates Global Inequalities in Taxing Rights. Working paper.

Landsman, W.R., Maydew, E.L., Thornock, J.R., 2012. The Information Content of Annual Earnings Announcements and Mandatory Adoption of IFRS. Journal of Accounting and Economics 53 (1-2) 34-54.

Leuz, C., Wysocki, P.D., 2016. The Economics of Disclosure and Financial Reporting Regulation: Evidence and Suggestions For Future Research. Journal of Accounting Research 54 (2) 525-622.

Levin, C., McCain, J., 2013. Offshore Profit Shifting and The Us Tax Code-Part 2 (Apple Inc.). Memorandum to the members of the Permanent Subcommittee on Investigations. May 21, 2013.

Mauler, L.M., 2019. The Effect of Analysts' Disaggregated Forecasts on Investors and Managers: Evidence Using Pre-Tax Forecasts. The Accounting Review 94 (3) 279-302.

OECD, 2013. Action Plan on Base Erosion and Profit Shifting: OECD Publishing.

OECD, 2015. Transfer Pricing Documentation and Country-by-Country Reporting - Action 13: 2015 Final Report, OECD/G20 Base Erosion and Profit Shifting Project Paris: OECD.

OECD, 2020. Country-by-Country Reporting - Compilation of Peer Review Reports (Phase 3), OECD/G20 Base Erosion and Profit Shifting Project Paris.

Ohlson, J.A., Penman, S.H., 1992. Disaggregated Accounting Data as Explanatory Variables For Returns. Journal of Accounting, Auditing \& Finance 7 (4) 553-573.

Senate Hearing 112-781, 2012. Offshore Profit Shifting and The U.S. Tax Code - Part 1 (Microsoft and Hewlett-Packard). Retrieved from http://www.gpo.gov/fdsys/pkg/CHRG112shrg76071/html/CHRG-112shrg76071.htm

Senate Hearing 113-90, 2013. Offshore Profit Shifting and The U.S. Tax Code - Part 2. Retrieved from $\quad$ https://www.gpo.gov/fdsys/pkg/CHRG-113shrg81657/pdf/CHRG113shrg81657.pdf

Tan, H., Wang, S., Welker, M., 2011. Analyst Following And Forecast Accuracy After Mandated IFRS Adoptions. Journal of Accounting Research 49 (5) 1307-1357. 
Thomas, J., Zhang, F., 2014. Valuation of Tax Expense. Review of Accounting Studies 19 (4) 1436-1467.

Thomas, J., Zhang, F.X., 2011. Tax Expense Momentum. Journal of Accounting Research 49 (3) 791-821.

Welker, M., 1995. Disclosure Policy, Information Asymmetry, and Liquidity in Equity Markets. Contemporary Accounting Research 11 (2) 801-827. 
Appendix A. Country-by-Country Reporting Adoption

\begin{tabular}{|c|c|c|c|}
\hline Country & $\begin{array}{l}\text { Start Date of First Fiscal } \\
\text { Year for Ultimate Parent } \\
\text { Entity's Filing }\end{array}$ & $\begin{array}{l}\text { CbCR Threshold (Local } \\
\text { Currency) }\end{array}$ & $\begin{array}{c}\text { CbCR Threshold } \\
\text { (Million USD as of the first } \\
\text { year of adoption) }\end{array}$ \\
\hline Argentina & $1 / 1 / 2017$ & EUR 750 million & 806.45 \\
\hline Australia & $1 / 1 / 2016$ & AUD 1 billion & 709.22 \\
\hline Austria & $1 / 1 / 2016$ & EUR 750 million & 815.22 \\
\hline Belgium & $1 / 1 / 2016$ & EUR 750 million & 815.22 \\
\hline Bermuda & $1 / 1 / 2016$ & EUR 750 million & 815.22 \\
\hline Brazil & $1 / 1 / 2016$ & BRL 2260 million & 553.92 \\
\hline Bulgaria & $1 / 1 / 2016$ & EUR 750 million & 815.22 \\
\hline Canada & $1 / 1 / 2016$ & EUR 750 million & 815.22 \\
\hline Chile & $1 / 1 / 2016$ & EUR 750 million & 815.22 \\
\hline China & $1 / 1 / 2016$ & RMB 5.5 billion & 835.87 \\
\hline Colombia & $1 / 1 / 2016$ & 81 million Tax Value Unit & 729.66 \\
\hline Denmark & $1 / 1 / 2016$ & DKK 5.6 billion & 819.91 \\
\hline Finland & $1 / 1 / 2016$ & EUR 750 million & 815.22 \\
\hline France & $1 / 1 / 2016$ & EUR 750 million & 815.22 \\
\hline Germany & $1 / 1 / 2016$ & EUR 750 million & 815.22 \\
\hline Greece & $1 / 1 / 2016$ & EUR 750 million & 815.22 \\
\hline India & $1 / 4 / 2016$ & INR 5500 crore & 826.82 \\
\hline Indonesia & $1 / 1 / 2016$ & IDR 11 trillion & 794.45 \\
\hline Ireland & $1 / 1 / 2016$ & EUR 750 million & 815.22 \\
\hline Italy & $1 / 1 / 2016$ & EUR 750 million & 815.22 \\
\hline Japan & $1 / 4 / 2016$ & JPY 100 billion & 894.93 \\
\hline Luxembourg & $1 / 1 / 2016$ & EUR 750 million & 815.22 \\
\hline Malaysia & $1 / 1 / 2017$ & MYR 3 billion & 677.20 \\
\hline Mexico & $1 / 1 / 2016$ & MXN 12 billion & 650.41 \\
\hline Netherlands & $1 / 1 / 2016$ & EUR 750 million & 815.22 \\
\hline New Zealand & $1 / 1 / 2016$ & EUR 750 million & 815.22 \\
\hline Norway & $1 / 1 / 2016$ & NOK 6.5 billion & 747.99 \\
\hline Pakistan & $1 / 1 / 2016$ & EUR 750 million & 815.22 \\
\hline Peru & $1 / 1 / 2017$ & PEN 2.7 billion & 823.17 \\
\hline Poland & $1 / 1 / 2016$ & EUR 750 million & 815.22 \\
\hline Portugal & $1 / 1 / 2016$ & EUR 750 million & 815.22 \\
\hline Qatar & $1 / 1 / 2017$ & QAR 3 billion & 824.18 \\
\hline Russia & $1 / 1 / 2017$ & RUB 50 billion & 831.12 \\
\hline Singapore & $1 / 1 / 2017$ & SGD 1.125 billion & 792.25 \\
\hline South Africa & $1 / 1 / 2016$ & ZAR 10 billion & 621.12 \\
\hline Spain & $1 / 1 / 2016$ & EUR 750 million & 815.22 \\
\hline South Korea & $1 / 1 / 2016$ & KRW 1 trillion & 833.96 \\
\hline Sweden & $1 / 1 / 2016$ & SEK 7 billion & 817.76 \\
\hline United Kingdom & $1 / 1 / 2016$ & EUR 750 million & 815.22 \\
\hline United States & $1 / 7 / 2016$ & USD 850 million & 850.00 \\
\hline Vietnam & $1 / 5 / 2017$ & VND 18,000 billion & 803.71 \\
\hline
\end{tabular}




\section{Appendix B. Variable Definition}

\begin{tabular}{|c|c|c|}
\hline Variable Name & Definition & Data Source \\
\hline$B H R_{i j t}$ & $\begin{array}{l}\text { Buy and hold returns for firm } i \text { in country } j \text { over a } 12 \text {-month beginning in the } \\
\text { fourth month of the current fiscal year } t \text {. We require the firm to have at least } \\
250 \text { days of non-missing daily returns to calculate cumulative returns. }\end{array}$ & $\begin{array}{l}\text { CRPS and } \\
\text { Security Daily }\end{array}$ \\
\hline UnTaxSurp $_{i j t}$ & $\begin{array}{l}\text { Unexplained tax surprise is measured as the residual of regressing tax surprise } \\
\text { on earnings surprise measured at the firm-year level. The regression is } \\
\text { performed by country that has at least } 40 \text { observations. Tax surprise is measured } \\
\text { as the year-to-year change in total tax expense scaled by the beginning of the } \\
\text { year assets. }\end{array}$ & $\begin{array}{l}\text { Compustat NA } \\
\text { and Compustat } \\
\text { Global }\end{array}$ \\
\hline EarnSurp $_{i j t}$ & $\begin{array}{l}\text { Earnings surprise is measured as the year-to-year change in pre-tax income } \\
\text { scaled by the beginning of year assets. }\end{array}$ & $\begin{array}{l}\text { Compustat NA } \\
\text { and Compustat } \\
\text { Global }\end{array}$ \\
\hline Treat $_{i j t}$ & $\begin{array}{l}\text { An indicator variable for treatment firms, equal to } 1 \text { if the firm's consolidated } \\
\text { revenue in the preceding year meets the CbCR threshold in any of the post- } \\
\text { implementation years, zero otherwise. }\end{array}$ & $\begin{array}{l}\text { OECD and } \\
\text { KPMG }\end{array}$ \\
\hline$C b C R_{t}$ & $\begin{array}{l}\text { An indicator variable equal to one for the post-implementation years, zero } \\
\text { otherwise. }\end{array}$ & $\begin{array}{l}\text { OECD and } \\
\text { KPMG }\end{array}$ \\
\hline TAXEXP_AFError ${ }_{i j t}$ & $\begin{array}{l}\text { Analysts' Tax Expense Forecast Error is measured as the absolute difference } \\
\text { between the mean estimate of analysts' tax expense forecast immediately } \\
\text { before the end of the fiscal year } t \text { and the actual tax expense for that fiscal year } \\
t \text {, scaled by the price at the end of the previous year }(t-1) \text {. We multiply the ratio } \\
\text { by } 100 \text { to facilitate interpretation. Tax expense is calculated as I/B/E/S-based } \\
\text { estimates of net income (NET) subtracted from } \mathrm{I} / \mathrm{B} / \mathrm{E} / \mathrm{S} \text {-based pre-tax income } \\
\text { (PRE). }\end{array}$ & $\begin{array}{l}\text { I/B/E/S, CRPS } \\
\text { and Security } \\
\text { Daily }\end{array}$ \\
\hline PRE_AFError ${ }_{i j t}$ & $\begin{array}{l}\text { Analyst Pre-tax Income Forecast Error is measured as the absolute difference } \\
\left.\text { between the average analyst pre-tax income forecast (PRE_AFMean } n_{i j t}\right) \\
\text { immediately before the end of the fiscal year } t \text { and the actual pre-tax income } \\
\text { for that fiscal year } t \text {, scaled by the price at the end of the previous year }(t-1) \text {. } \\
\text { We multiply the ratio by } 100 \text { to facilitate interpretation. }\end{array}$ & $\begin{array}{l}\mathrm{I} / \mathrm{B} / \mathrm{E} / \mathrm{S}, \mathrm{CRPS} \\
\text { and Security } \\
\text { Daily }\end{array}$ \\
\hline$P R E \_A F_{i j t}$ & $\begin{array}{l}\text { Analyst Pre-tax Income Forecast is measured as the mean estimate of analyst } \\
\text { pre-tax income forecast immediately before the end of the fiscal year } t \text { scaled } \\
\text { by the price at the end of the previous year }(t-1) \text {. }\end{array}$ & $\begin{array}{l}\text { I/B/E/S, CRPS } \\
\text { and Security } \\
\text { Daily }\end{array}$ \\
\hline NET_AFError $r_{i j t}$ & $\begin{array}{l}\text { Analyst Net Income Forecast Error is measured as the absolute difference } \\
\text { between the average analyst after-tax income forecast immediately before the } \\
\text { end of the fiscal year } t \text { and the actual after-tax income for that fiscal year } t \text {, } \\
\text { scaled by the price at the end of the previous year }(t-1) \text {. We multiply the ratio } \\
\text { by } 100 \text { to facilitate interpretation. }\end{array}$ & $\begin{array}{l}\text { I/B/E/S, CRPS } \\
\text { and Security } \\
\text { Daily }\end{array}$ \\
\hline Tax_Misalignment $_{i j t}$ & $\begin{array}{l}\text { The misalignment between tax and economic activities is measured by the } \\
\text { absolute value of unexplained analysts' tax forecast error by economic } \\
\text { activities. Specifically, we use absolute value of the residual term from } \\
\text { estimating equation }(6) \text { by country: TAXEXP_AFError } r_{i j t}=\beta_{1} P R E \_A F E r r o r_{i j t}+ \\
\beta_{2} P R E_{-} A F_{i j t}+\tau_{i j t .}\end{array}$ & $\begin{array}{l}\text { I/B/E/S, CRPS } \\
\text { and Security } \\
\text { Daily }\end{array}$ \\
\hline SalesGrowth $_{i j t}$ & $\begin{array}{l}\text { Sales growth is calculated as the year-to-year change in sales scaled by the } \\
\text { beginning of year sales. Missing value is set to zero. }\end{array}$ & $\begin{array}{l}\text { Compustat NA } \\
\text { and Compustat } \\
\text { Global }\end{array}$ \\
\hline Pre_AFDisp ${ }_{i j t}$ & $\begin{array}{l}\text { Standard deviation of the analyst pre-tax earnings forecasts during the year } \\
\text { before the earnings announcement. }\end{array}$ & $\mathrm{I} / \mathrm{B} / \mathrm{E} / \mathrm{S}$ \\
\hline
\end{tabular}




\section{Appendix B. Variable Definition (Cont.)}

\begin{tabular}{|c|c|c|}
\hline Variable Name & Definition & Data Source \\
\hline ShareTurnover $_{i j t}$ & $\begin{array}{l}\text { Stock share turnover is calculated as the total number of shares traded during } \\
\text { the year scaled by the average number of shares outstanding for that year. }\end{array}$ & $\begin{array}{l}\text { CRPS and } \\
\text { Security Daily }\end{array}$ \\
\hline AnalystFollowing $_{i j t}$ & $\begin{array}{l}\text { The number of analysts issuing both pre-tax and after-tax earnings forecasts } \\
\text { immediately before the end of the fiscal year } t \text {. }\end{array}$ & $\mathrm{I} / \mathrm{B} / \mathrm{E} / \mathrm{S}$ \\
\hline MarketValue $_{i j t}$ & $\begin{array}{l}\text { Nature logarithm of the firm's equity market value, which is measured as the } \\
\text { price per share multiplied by the number of shares outstanding in millions at } \\
\text { the end of the year. }\end{array}$ & $\begin{array}{l}\text { Compustat NA } \\
\text { and Compustat } \\
\text { Global }\end{array}$ \\
\hline Leverage $_{i j t}$ & Ratio of long-term debt to the beginning of year assets. & $\begin{array}{l}\text { Compustat NA } \\
\text { and Compustat } \\
\text { Global }\end{array}$ \\
\hline Revenue $_{i j t}$ & Total consolidated revenue for the firm at the end of fiscal year $t$. & $\begin{array}{l}\text { Compustat NA } \\
\text { and Compustat } \\
\text { Global }\end{array}$ \\
\hline$B 2 M_{i j t}$ & $\begin{array}{l}\text { Book-to-market ratio is measured as the total shareholders' equity divided by } \\
\text { the market value of equity at the end of the year. }\end{array}$ & $\begin{array}{l}\text { Compustat NA } \\
\text { and Compustat } \\
\text { Global }\end{array}$ \\
\hline Return $_{i j t}$ & 12-month cumulative stock return based on compounded daily returns. & $\begin{array}{l}\text { CRPS and } \\
\text { Security Daily }\end{array}$ \\
\hline
\end{tabular}




\section{Appendix C. Transform two-stage equations into a single equation}

Chen et al. (2018b) suggest that a two-stage procedure that uses residuals from the first-stage regression as the dependent variable in the second-stage regression could cause biased coefficient estimates, and it is important to show the robustness of results using a single equation. To alleviate this concern, we use this Appendix to illustrate how we test the impact of CbCR on misalignment perceived by capital markets (Tax_Misalignment) in a single equation. Note that Tax_Misalignment is the absolute value of residuals estimated from equation (6), which we use as the dependent variable in equation (7). We next illustrate how we construct a single equation that combines both equations (6) and (7). We begin with equation (7) and suppress the subscripts for brevity,

$$
|\tau|=\gamma_{0}+\gamma_{1} \text { Treat }^{*} C b C R+\sum \gamma_{k} \text { Control }_{k}
$$

Where $\tau$ is the residual estimated from equation (6) and we can express $\tau$ as a function of (TAXEXP_AFError $\left.\beta_{1} P R E \_A F E r r o r-\beta_{2} P R E \_A F\right)$ by rearranging terms in equation (6). By substituting $\tau$ in equation (7) using the expression above, we have the following equation,

$$
\left|T A X E X P \_A F E r r o r-\beta_{1} P R E_{-} A F E r r o r-\beta_{2} P R E_{-} A F\right|=\gamma_{0}+\gamma_{1} \text { Treat }^{*} C b C R+\sum \gamma_{k} \text { Control }_{k} \text {. }
$$

To estimate equation (A1) in a regression framework, we take the following two steps to account for the effect of the absolute value in the dependent variable.

In step one, if TAXEXP_AFError $\geq\left(\beta_{1} P R E_{-} A F E r r o r-\beta_{2} P R E \_A F\right)$, then |TAXEXP_AFError $\beta_{1} P R E \_A F E r r o r-\beta_{2} P R E \_A F \mid$ is equivalent to $\left(T A X E X P \_A F E r r o r-\beta_{1} P R E \_A F E r r o r-\beta_{2} P R E \_A F\right)$. After rearranging terms in equation (A1), We can estimate the following regression when TAXEXP_AFError $\geq$ $\left(\beta_{1} P R E \_A F E r r o r-\beta_{2} P R E \_A F\right)$,

$$
\text { TAXEXP_AFError }=\beta_{1} P R E \_A F E r r o r+\beta_{2} P R E \_A F+\gamma_{0}+\gamma_{1} \text { Treat } * C b C R+\sum \gamma_{k} \text { Control }_{k} \text {. }
$$

In step two, if TAXEXP_AFError $<\left(\beta_{1} P R E \_A F E r r o r-\beta_{2} P R E \_A F\right)$, then |TAXEXP_AFError $\beta_{1} P R E \_A F E r r o r-\beta_{2} P R E \_A F \mid$ is equivalent to $\left(-T A X E X P \_A F E r r o r+\beta_{1} P R E \_A F E r r o r+\beta_{2} P R E \_A F\right)$. After rearranging terms in equation (A1), We can estimate the following regression when TAXEXP_AFError $<$ $\left(\beta_{1} P R E \_A F E r r o r-\beta_{2} P R E \_A F\right)$,

$$
\begin{aligned}
\left(-T A X E X P \_A F E r r o r\right)=\beta_{1} & \left(-P R E \_A F E r r o r\right)+\beta_{2}\left(-P R E \_A F\right) \\
& +\gamma_{0}+\gamma_{1} \text { Treat }^{*} C b C R+\sum \gamma_{k} \text { Control }_{k} .
\end{aligned}
$$


To combine Equations (A2) and (A3) in a single equation, we separately transform TAXEXP_AFError, PRE_AFError and PRE_AF by multiplying each by negative one when TAXEXP_AFError $<\left(\beta_{1} P R E \_A F E r r o r-\right.$ $\left.\beta_{2} P R E \_A F\right)$, and keep their value the same when $T A X E X P \_A F E r r o r \geq\left(\beta_{1} P R E \_A F E r r o r-\beta_{2} P R E \_A F\right)$. We report the single equation based on transformed variables, denoted by the upper script ${ }^{T}$, below,

$$
\begin{aligned}
& \text { TAXEXP_AFError }{ }^{T}=\beta_{1} P R E_{-} A F E r r o r^{T}+\beta_{2} P R E \_A F^{T} \\
& +\gamma_{0}+\gamma_{1} \text { Treat }^{*} \text { CbCR }+\sum \gamma_{k} \text { Control }_{k} \text {. }
\end{aligned}
$$

We report results from estimating equation (A4) in Table 5 Panel A Column (2). This single-equation test serves as a robustness check for the two-stage regression results reported in Table 5 Panel A Column (1). 


\section{Table 1. Sample Selection}

\begin{tabular}{lr}
\hline Panel A: Main Sample & Obs \\
\hline Compustat NA and Global firms with I/B/E/S data between 2012 and 2019 from countries & 102,593 \\
mandating CbCR: & $(4,159)$ \\
Less: firm-year observations with headquarter location different from country of & $(715)$ \\
incorporation & $(15,590)$ \\
$\quad$ Countries with less than 100 firm-year observations & 82,129 \\
$\quad$ Firms with less than one year of observations in the post-CBCR period & 82,129 \\
\hline Total number of firm-country-year observations & $(14,380)$ \\
& $(27,626)$ \\
\hline Panel B: Subsample for Analyst Forecast Accuracy Tests & 40,123 \\
\hline Less: Observations with missing values in analyst forecasts & 82,129 \\
\hline Observations with missing values in Equation (7) & $(14,380)$ \\
& $(7,973)$ \\
\hline Panel C: Subsample for Value Relevance Tests & $(5,571)$ \\
\hline Less: Observations with missing values in analyst forecasts & 54,205 \\
$\quad$ Observations with missing buy-and-hold returns \\
Observations with missing values in equation (8)
\end{tabular}


Table 2. Sample Distribution by Country

\begin{tabular}{|c|c|c|c|c|c|c|c|c|}
\hline & \multicolumn{4}{|c|}{ Analyst Forecast Accuracy } & \multicolumn{4}{|c|}{ Value Relevance } \\
\hline & $(1)$ & $(2)$ & $(3)$ & (4) & $(5)$ & $(6)$ & $(7)$ & $(8)$ \\
\hline Country & \# Firms & $\begin{array}{l}\text { \# Firm-Year } \\
\text { Observations }\end{array}$ & $\begin{array}{l}\text { Percentage of } \\
\text { Observations }\end{array}$ & $\begin{array}{c}\operatorname{Mean}(\text { Tax_Mis } \\
\left.\text { alignment }_{i j t}\right)\end{array}$ & \# Firms & $\begin{array}{l}\text { \# Firm-Year } \\
\text { Observations }\end{array}$ & $\begin{array}{l}\text { Percentage of } \\
\text { Observations }\end{array}$ & $\begin{array}{c}\text { Mean }(\text { Tax_Mis } \\
\left.\text { alignment }_{i j t}\right)\end{array}$ \\
\hline Argentina & 4 & 19 & $0.05 \%$ & 1.511 & 6 & 51 & $0.09 \%$ & 2.168 \\
\hline Australia & 304 & 1,614 & $4.02 \%$ & 0.864 & 361 & 2,205 & $4.07 \%$ & 0.951 \\
\hline Austria & 29 & 200 & $0.50 \%$ & 0.882 & 28 & 213 & $0.39 \%$ & 0.878 \\
\hline Belgium & 38 & 193 & $0.48 \%$ & 0.993 & 51 & 321 & $0.59 \%$ & 1.063 \\
\hline Bulgaria & 1 & 2 & $0.00 \%$ & 0.222 & 7 & 32 & $0.06 \%$ & 0.475 \\
\hline Bermuda & 11 & 56 & $0.14 \%$ & 0.822 & 11 & 65 & $0.12 \%$ & 0.847 \\
\hline Brazil & 111 & 577 & $1.44 \%$ & 1.537 & 123 & 703 & $1.30 \%$ & 1.558 \\
\hline Canada & 27 & 140 & $0.35 \%$ & 1.180 & 234 & 1,315 & $2.43 \%$ & 1.205 \\
\hline Chile & 20 & 124 & $0.31 \%$ & 0.001 & 26 & 166 & $0.31 \%$ & 0.001 \\
\hline China & 1,124 & 5,167 & $12.88 \%$ & 0.448 & 1,396 & 7,628 & $14.07 \%$ & 0.449 \\
\hline Colombia & 6 & 39 & $0.10 \%$ & 0.001 & 11 & 69 & $0.13 \%$ & 0.001 \\
\hline Germany & 212 & 1,178 & $2.94 \%$ & 0.957 & 253 & 1,538 & $2.84 \%$ & 0.977 \\
\hline Denmark & 9 & 38 & $0.09 \%$ & 0.721 & 9 & 49 & $0.09 \%$ & 0.991 \\
\hline Spain & 64 & 334 & $0.83 \%$ & 1.143 & 66 & 371 & $0.68 \%$ & 1.036 \\
\hline Finland & 60 & 349 & $0.87 \%$ & 0.993 & 79 & 456 & $0.84 \%$ & 1.140 \\
\hline France & 176 & 858 & $2.14 \%$ & 0.961 & 244 & 1,442 & $2.66 \%$ & 1.062 \\
\hline United Kingdom & 414 & 2,147 & $5.35 \%$ & 0.999 & 507 & 2,990 & $5.52 \%$ & 1.030 \\
\hline Greece & 19 & 100 & $0.25 \%$ & 2.383 & 27 & 141 & $0.26 \%$ & 2.260 \\
\hline Indonesia & 93 & 493 & $1.23 \%$ & 0.007 & 107 & 611 & $1.13 \%$ & 0.012 \\
\hline India & 364 & 2,175 & $5.42 \%$ & 0.735 & 495 & 3,052 & $5.63 \%$ & 0.706 \\
\hline Ireland & 26 & 126 & $0.31 \%$ & 0.652 & 23 & 123 & $0.23 \%$ & 0.689 \\
\hline Italy & 86 & 458 & $1.14 \%$ & 1.027 & 123 & 736 & $1.36 \%$ & 1.185 \\
\hline Japan & 1,146 & 6,760 & $16.85 \%$ & 0.001 & 2,457 & 16,459 & $30.36 \%$ & 0.002 \\
\hline Luxembourg & 16 & 81 & $0.20 \%$ & 1.199 & 16 & 82 & $0.15 \%$ & 0.958 \\
\hline Mexico & 50 & 276 & $0.69 \%$ & 0.952 & 62 & 331 & $0.61 \%$ & 0.997 \\
\hline
\end{tabular}


Table 2. Sample Distribution by Country (Cont'd)

\begin{tabular}{|c|c|c|c|c|c|c|c|c|}
\hline & \multicolumn{4}{|c|}{ Analyst Forecast Accuracy } & \multicolumn{4}{|c|}{ Value Relevance } \\
\hline & $(1)$ & $(2)$ & $(3)$ & $(4)$ & $(5)$ & $(6)$ & $(7)$ & $(8)$ \\
\hline Country & \# Firms & $\begin{array}{l}\text { \# Firm-Year } \\
\text { Observations }\end{array}$ & $\begin{array}{l}\text { Percentage of } \\
\text { Observations }\end{array}$ & $\begin{array}{c}\text { Mean(Tax_Mis } \\
\left.\text { alignment }_{i j t}\right)\end{array}$ & \# Firms & $\begin{array}{l}\text { \# Firm-Year } \\
\text { Observations }\end{array}$ & $\begin{array}{l}\text { Percentage of } \\
\text { Observations }\end{array}$ & $\begin{array}{c}\text { Mean }(\text { Tax_Mis } \\
\left.\text { alignment }_{i j t}\right)\end{array}$ \\
\hline Malaysia & 157 & 858 & $2.14 \%$ & 0.923 & 207 & 1,236 & $2.28 \%$ & 0.933 \\
\hline Netherlands & 49 & 260 & $0.65 \%$ & 1.343 & 54 & 311 & $0.57 \%$ & 1.243 \\
\hline Norway & 87 & 451 & $1.12 \%$ & 1.261 & 97 & 559 & $1.03 \%$ & 1.249 \\
\hline New Zealand & 42 & 283 & $0.71 \%$ & 0.837 & 50 & 352 & $0.65 \%$ & 0.912 \\
\hline Pakistan & 33 & 167 & $0.42 \%$ & 0.879 & 45 & 250 & $0.46 \%$ & 0.914 \\
\hline Peru & 2 & 5 & $0.01 \%$ & 0.137 & 7 & 51 & $0.09 \%$ & 0.869 \\
\hline Poland & 92 & 392 & $0.98 \%$ & 0.907 & 122 & 650 & $1.20 \%$ & 0.920 \\
\hline Portugal & 18 & 94 & $0.23 \%$ & 1.057 & 18 & 106 & $0.20 \%$ & 1.045 \\
\hline Qatar & 13 & 62 & $0.15 \%$ & 0.325 & 14 & 86 & $0.16 \%$ & 0.274 \\
\hline Russia & 49 & 218 & $0.54 \%$ & 1.443 & 52 & 282 & $0.52 \%$ & 1.405 \\
\hline Singapore & 76 & 387 & $0.96 \%$ & 0.705 & 94 & 521 & $0.96 \%$ & 0.794 \\
\hline South Africa & 73 & 409 & $1.02 \%$ & 1.111 & 93 & 540 & $1.00 \%$ & 1.212 \\
\hline South Korea & 342 & 1,699 & $4.23 \%$ & 0.009 & 401 & 2,253 & $4.16 \%$ & 0.008 \\
\hline Sweden & 115 & 561 & $1.40 \%$ & 0.739 & 157 & 838 & $1.55 \%$ & 0.849 \\
\hline United States & 2,084 & 10,557 & $26.31 \%$ & 0.611 & 1,064 & 4,697 & $8.67 \%$ & 0.506 \\
\hline Vietnam & 58 & 216 & $0.54 \%$ & 0.742 & 67 & 324 & $0.60 \%$ & 0.751 \\
\hline Total & 7,700 & 40,123 & $100 \%$ & & 9,264 & 54,205 & $100 \%$ & \\
\hline
\end{tabular}


Table 3. Descriptive Statistics

\begin{tabular}{|c|c|c|c|c|c|c|c|c|c|c|c|c|}
\hline \multicolumn{13}{|c|}{ Panel A: Analyst Forecast Accuracy Subsample } \\
\hline \multirow[b]{3}{*}{ TAXEXP_AFError ${ }_{i j t}$} & \multicolumn{6}{|c|}{ Treatment Group } & \multicolumn{6}{|c|}{ Control Group } \\
\hline & $\mathrm{N}$ & Mean & Std. Dev. & P25 & Median & P75 & $\mathrm{N}$ & Mean & Std. Dev. & P25 & Median & P75 \\
\hline & 22,902 & 0.008 & 0.022 & 0.000 & 0.001 & 0.006 & 17,221 & 0.008 & 0.022 & 0.000 & 0.001 & 0.005 \\
\hline PRE_AFError $r_{i j t}$ & 22,902 & $0.014 * * *$ & 0.042 & 0.000 & 0.003 & 0.010 & 17,221 & 0.016 & 0.043 & 0.001 & 0.004 & 0.012 \\
\hline NET_AFError ${ }_{i j t}$ & 22,902 & $0.010 * * *$ & 0.035 & 0.000 & 0.002 & 0.007 & 17,221 & 0.013 & 0.038 & 0.000 & 0.003 & 0.009 \\
\hline SalesGrowth $_{i j t}$ & 22,902 & $0.050 * * *$ & 0.177 & 0.000 & 0.000 & 0.077 & 17,221 & 0.087 & 0.256 & 0.000 & 0.000 & 0.127 \\
\hline PRE_AFDisp $p_{i j t}$ & 22,902 & $0.845^{* * *}$ & 2.668 & 0.029 & 0.137 & 0.494 & 17,221 & 0.717 & 2.782 & 0.017 & 0.068 & 0.262 \\
\hline AnalystFollowing $_{i j t}$ & 22,902 & $11.770^{* * *}$ & 8.171 & 5.000 & 10.000 & 16.000 & 17,221 & 5.511 & 4.096 & 3.000 & 4.000 & 7.000 \\
\hline ShareTurnover $_{i j t}$ & 22,902 & $1.524 * * *$ & 1.530 & 0.568 & 1.063 & 1.929 & 17,221 & 1.664 & 1.959 & 0.370 & 0.919 & 2.198 \\
\hline Leverage $_{i j t}$ & 22,902 & $0.204 * * *$ & 0.184 & 0.058 & 0.167 & 0.299 & 17,221 & 0.144 & 0.194 & 0.000 & 0.058 & 0.225 \\
\hline MarketValue $_{i j t}$ & 22,902 & $8.191 * * *$ & 1.356 & 7.256 & 8.098 & 9.065 & 17,221 & 6.218 & 1.206 & 5.403 & 6.276 & 7.068 \\
\hline \multicolumn{13}{|c|}{ Panel B: Value Relevance Subsample } \\
\hline & \multicolumn{6}{|c|}{ Treatment Group } & \multicolumn{6}{|c|}{ Control Group } \\
\hline & $\mathrm{N}$ & Mean & Std. Dev. & P25 & Median & P75 & $\mathrm{N}$ & Mean & Std. Dev. & P25 & Median & P75 \\
\hline$B H R_{i j t}$ & 23,800 & $0.170^{* * *}$ & 0.555 & -0.111 & 0.081 & 0.304 & 30,405 & 0.186 & 0.646 & -0.162 & 0.065 & 0.343 \\
\hline UnTaxSurp $_{i j t}$ & 23,800 & $0.000^{*}$ & 0.013 & -0.004 & 0.000 & 0.004 & 30,405 & 0.000 & 0.016 & -0.005 & 0.000 & 0.005 \\
\hline EarnSurp $_{i j t}$ & 23,800 & $0.005^{*}$ & 0.046 & -0.006 & 0.003 & 0.015 & 30,405 & 0.006 & 0.075 & -0.012 & 0.004 & 0.023 \\
\hline MarketValue $_{i j t}$ & 23,800 & $7.988 * * *$ & 1.544 & 6.993 & 7.886 & 8.888 & 30,405 & 5.466 & 1.487 & 4.417 & 5.454 & 6.546 \\
\hline$B 2 M_{i j t}$ & 23,800 & $0.861 * * *$ & 0.750 & 0.369 & 0.657 & 1.103 & 30,405 & 0.918 & 0.820 & 0.328 & 0.657 & 1.240 \\
\hline Return $_{t i j-1}$ & 23,800 & $0.167 * * *$ & 0.400 & -0.077 & 0.110 & 0.332 & 30,405 & 0.218 & 0.523 & -0.094 & 0.114 & 0.390 \\
\hline Revenue $_{i j t-1}$ & 23,800 & $6,785.71 * * *$ & $10,806.09$ & $1,274.41$ & $2,457.87$ & $6,385.91$ & 30,405 & 265.46 & 365.76 & 84.93 & 195.97 & 387.92 \\
\hline
\end{tabular}


Table 5. CbCR and Misalignment

\begin{tabular}{|c|c|c|}
\hline \multicolumn{3}{|c|}{ Panel A: Difference-in-difference design } \\
\hline \multirow[t]{3}{*}{ Dependent Variable $=$} & Tax_Misalignment $t_{i j t}$ & TAXEXP_AFError ${ }_{i j t}^{T}$ \\
\hline & Two-stage residual approach & Single-equation approach \\
\hline & $(1)$ & $(2)$ \\
\hline \multirow[t]{2}{*}{ Treat $_{i j t} \times C b C R_{t}$} & $-0.068 * *$ & $-0.059 * * *$ \\
\hline & $(0.011)$ & $(0.003)$ \\
\hline \multirow[t]{2}{*}{$P R E_{-} A F E r r o r_{i j t}^{T}$} & & -8.745 \\
\hline & & $(0.922)$ \\
\hline \multirow[t]{2}{*}{$P R E_{-} A F_{i j t}^{T}$} & & -20.216 \\
\hline & & $(0.819)$ \\
\hline \multirow[t]{2}{*}{ SalesGrowth $_{i j t}$} & -0.041 & -0.021 \\
\hline & $(0.516)$ & $(0.449)$ \\
\hline \multirow[t]{2}{*}{ PRE_AFDisp ${ }_{i j t}$} & $0.077 * * *$ & $0.049 * * *$ \\
\hline & $(0.003)$ & $(0.000)$ \\
\hline \multirow[t]{2}{*}{ AnalystFollowing $_{i j t}$} & 0.002 & 0.000 \\
\hline & $(0.386)$ & $(0.908)$ \\
\hline \multirow[t]{2}{*}{ ShareTurnover $_{i j t}$} & $0.051 * *$ & $0.044 * * *$ \\
\hline & $(0.019)$ & $(0.000)$ \\
\hline \multirow[t]{2}{*}{ Leverage $_{i j t}$} & $-0.149 *$ & $-0.160 * * *$ \\
\hline & $(0.055)$ & $(0.006)$ \\
\hline \multirow[t]{2}{*}{ MarketValue $_{i j t}$} & $-0.728 * * *$ & $-0.632 * * *$ \\
\hline & $(0.000)$ & $(0.000)$ \\
\hline Firm F.E. & $\mathrm{Y}$ & Y \\
\hline Country-Year FE & $\mathrm{Y}$ & Y \\
\hline$N$ & 40,123 & 40,123 \\
\hline $\operatorname{Adj}-R^{2}$ & 0.4550 & 0.6282 \\
\hline
\end{tabular}

Notes: Column (1) reports results of estimating equation (7) based on the analyst forecast accuracy subsample defined in Table 1.

$$
\text { Tax_Misalignment }_{i j t}=\gamma_{0}+\gamma_{1} \text { Treat }_{i j t} * C_{C} C R_{t}+\sum \gamma_{k} \text { Control }_{k}+\sum F E_{d}+\varepsilon_{i j t} .
$$

The dependent variable (Tax_Misalignment) is the absolute value of residuals of estimating the first-stage equation (6) as reported in Table 4. Column (1) is based on the two-stage residual approach. In column (2), we combine the two-stage equations from column (1) into a single Equation (A4) as illustrated in Appendix C and use transformed analysts' tax forecast error as the depending variable.

$$
\begin{aligned}
\text { TAXEXP_AFError } & =\beta_{1} P R E_{-} \text {AFError } \\
& +\beta_{2} P R E \_A F^{T} \\
& +\gamma_{0}+\gamma_{1} \text { Treat }^{*} \text { CbCR }
\end{aligned}
$$

Where TAXEXP_AFError ${ }_{i j t}^{T}$, PRE_AFError ${ }_{i j t}^{T}$, and $P R E_{-} A F_{i j t}^{T}$ are separately transformed variables from TAXEXP_AFError $i_{i j t}$ PRE_AFError $r_{i j t}$ and PRE_AF $F_{i j t}$ to account for the absolute value of Tax_Misalignment. See Appendix $\mathrm{C}$ for a definition of these transformed variables. To be consistent with estimating Tax_Misalignment based on country-level portfolios as reported in Table 4, we follow Chen et al. (2018b) and interact each transformed independent variable from equation (6) with country indicator variables. We suppress reporting these coefficient estimates for brevity. Robust p-values in parentheses are calculated based on standard error clustered by country. All continuous variables are winsorized at the 1 percent level. All other variables are defined in Appendix A. **, *** indicate statistical significance at the 0.05 and 0.01 levels, respectively. 
Figure 1. Misalignment and Discontinuities around the CbCR Threshold

a. Density Plot of Firms' Consolidated Revenue around the Threshold
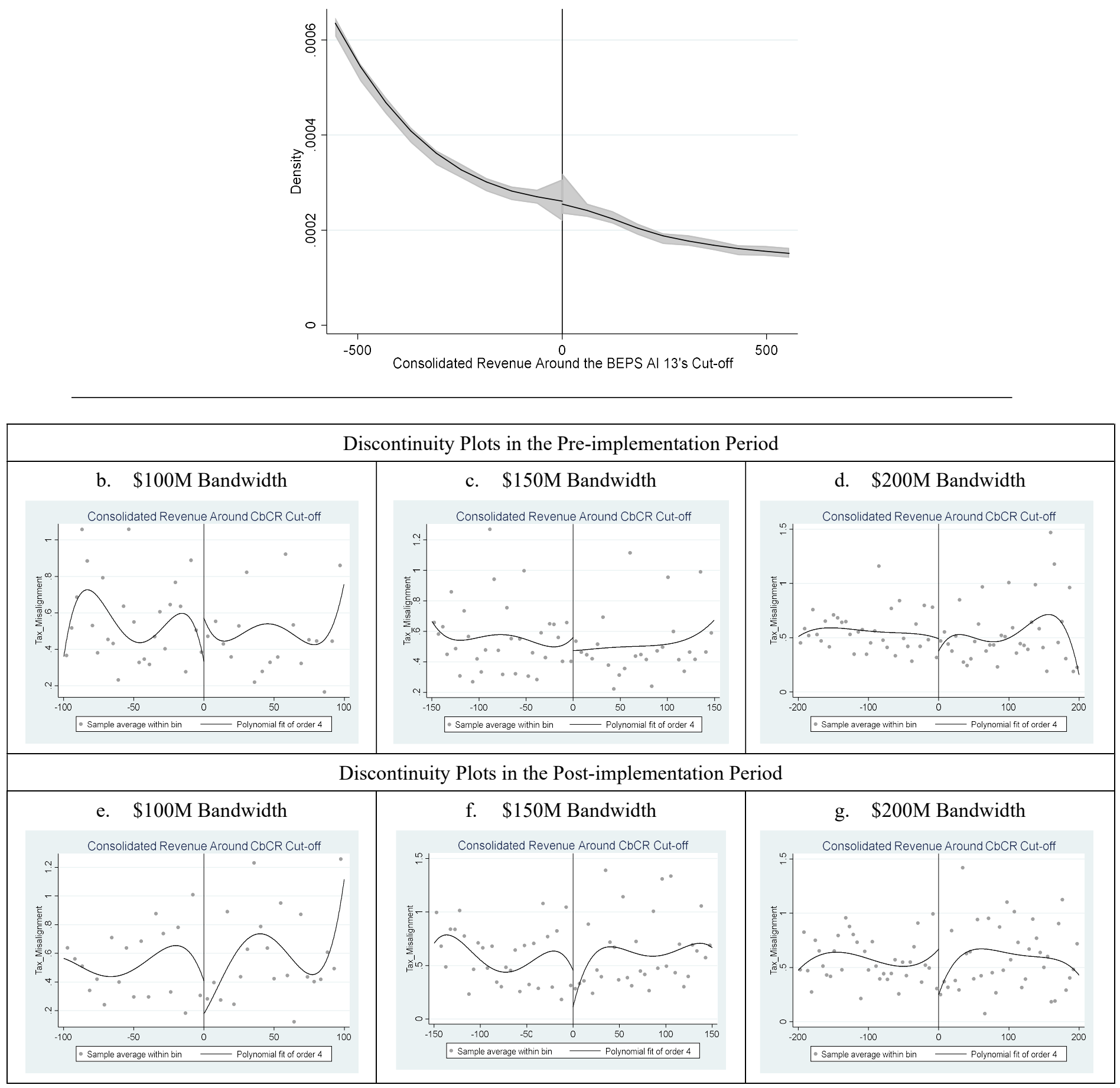

Notes - Figure 1a plots the consolidated revenue density around the $\mathrm{CbCR}$ reporting threshold, represented by the vertical line. Figures 1b-d (1e-f) separately plot Tax_Misalignment $t_{i j t}$, which is the absolute value of residuals of estimating equation (6) as reported in Table 4 , in the pre- (post-) implementation periods for both the treatment group (above the consolidated revenue threshold) and control group (below the threshold) for the $\$ 100 \mathrm{M}, \$ 150 \mathrm{M}$, and $\$ 200 \mathrm{M}$ bandwidths using fourth order polynomial fit to approximate the population conditional expectation functions for control and treated observations. The vertical line indicates whether the firms are above or below the CbCR cutoff. 
Table 5. CbCR and Misalignment (Cont'd)

\begin{tabular}{|c|c|c|c|c|}
\hline \multicolumn{5}{|c|}{ Panel B: Regression Discontinuity with Controls and Fixed Effects } \\
\hline \multicolumn{5}{|c|}{ Panel B1: Regression Discontinuity in the pre-implementation period } \\
\hline Bandwidth & Optimal & $100 \mathrm{M}$ & $150 \mathrm{M}$ & $200 \mathrm{M}$ \\
\hline Tax_Misalignment ${ }_{i j t}$ & -0.069 & -0.086 & -0.019 & -0.019 \\
\hline \multicolumn{5}{|c|}{ Panel B2: Regression Discontinuity in the post-implementation period } \\
\hline Bandwidth & Optimal & $100 \mathrm{M}$ & $150 \mathrm{M}$ & $200 \mathrm{M}$ \\
\hline Tax_Misalignment $t_{j t}$ & -0.089 & $-0.388^{* *}$ & $-0.309^{* *}$ & -0.208 \\
\hline \multicolumn{5}{|c|}{ 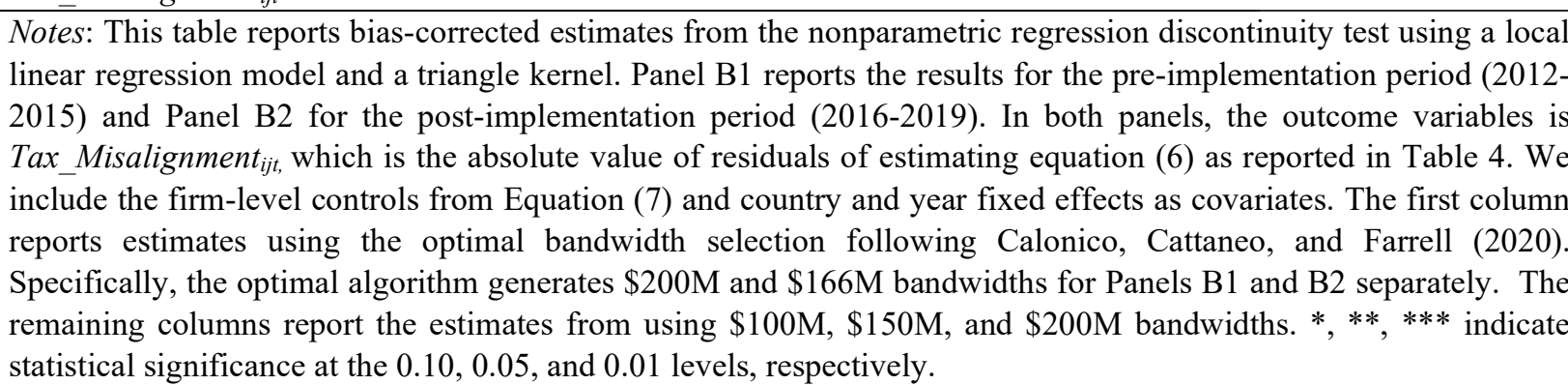 } \\
\hline
\end{tabular}


Table 6. CbCR and Analysts' Tax Forecast Accuracy

\begin{tabular}{|c|c|c|c|}
\hline \multirow[t]{3}{*}{ Dependent Variable $=$} & \multicolumn{3}{|c|}{$\begin{array}{c}\text { Tax Expense Forecast Error } \\
\text { TAXEXP_AFError }{ }_{i j t}\end{array}$} \\
\hline & \multirow{2}{*}{ Main Regression } & Low & High \\
\hline & & Misalignment & Misalignment \\
\hline & $(1)$ & $(2)$ & (3) \\
\hline \multirow[t]{2}{*}{ Treat $_{i j t} \times \mathrm{CbCR}_{t}$} & $-0.001 *$ & -0.000 & $-0.001 *$ \\
\hline & $(0.098)$ & $(0.997)$ & $(0.094)$ \\
\hline \multirow{2}{*}{ SalesGrowth $_{i j t}$} & -0.001 & 0.000 & $-0.003 *$ \\
\hline & $(0.406)$ & $(0.164)$ & $(0.085)$ \\
\hline \multirow[t]{2}{*}{ PRE_AFDisp $p_{i j t}$} & $0.002 * *$ & $0.000^{* *}$ & $0.003^{* * *}$ \\
\hline & $(0.016)$ & $(0.012)$ & $(0.009)$ \\
\hline \multirow[t]{2}{*}{ AnalystFollowing $_{i j t}$} & 0.000 & $-0.000^{*}$ & -0.000 \\
\hline & $(0.555)$ & $(0.092)$ & $(0.709)$ \\
\hline \multirow[t]{2}{*}{ ShareTurnover $_{i j t}$} & $0.001 * *$ & $0.000 * * *$ & $0.002 * * *$ \\
\hline & $(0.016)$ & $(0.005)$ & $(0.004)$ \\
\hline \multirow[t]{2}{*}{ Leverage $_{i j t}$} & $-0.003 * *$ & -0.001 & -0.004 \\
\hline & $(0.025)$ & $(0.516)$ & $(0.156)$ \\
\hline \multirow[t]{2}{*}{ MarketValue $_{i j t}$} & $-0.012 * * *$ & $-0.002 * *$ & $-0.017 * * *$ \\
\hline & $(0.000)$ & $(0.021)$ & $(0.000)$ \\
\hline $\begin{array}{l}\text { Treat } \times C b C R^{\text {High }}- \\
\text { Treat } \times C b C R^{\text {Low }}=0 \\
(\mathrm{p} \text {-value) }\end{array}$ & & \multicolumn{2}{|c|}{$\begin{array}{c}-0.001 \\
(0.117)\end{array}$} \\
\hline Firm F.E. & Yes & Yes & Yes \\
\hline Country-Year FE & Yes & Yes & Yes \\
\hline $\mathrm{N}$ & 40,123 & 20,198 & 19,925 \\
\hline Adjusted $\mathrm{R}^{2}$ & 0.4478 & 0.2016 & 0.4293 \\
\hline
\end{tabular}

Notes: This table reports results of estimating adapted equation (7) based on the analyst forecast accuracy sample defined in Table 1 and based on subsamples partitioned by the level of misalignment in the pre-implementation period.

Tax_Misalignment ${ }_{i j t}=\gamma_{0}+\gamma_{1}$ Treat $_{i j t} * C_{b C R_{t}}+\sum \gamma_{k}$ Control $_{k}+\sum F E_{d}+\varepsilon_{i j t}$.

In all columns, we adapt equation (7) by replacing the dependent variable using analysts' tax forecast error. In column (1), we estimate the regression for the analyst forecast accuracy full sample. In columns (2) and (3), we partition the sample based on the firm's level of misalignment before the CbCR implementation. A firm has low (high) pre-CbCR misalignment if its average value of Tax_Misalignment tijt before CbCR adoption is below (above) the sample median. At the bottom of the table, we compare the coefficients on Treat $\times C b C R$ using z-tests across low and high misalignment subsamples. Robust p-values in parentheses are calculated based on standard error clustered by country. All continuous variables are winsorized at the 1 percent level. All variables are defined in Appendix A. $*, * *, * * *$ indicate statistical significance at the $0.10,0.05$, and 0.01 levels, respectively. 
Table 7. CbCR and Value Relevance of Tax

\begin{tabular}{|c|c|c|c|}
\hline \multirow[t]{2}{*}{ Dependent Variable $=$} & \multicolumn{3}{|c|}{$\begin{array}{l}\text { 12-month Buy-and-hold Return } \\
\qquad B H R_{i j t}\end{array}$} \\
\hline & Main Regression & $\begin{array}{l}\text { Low } \\
\text { Misalignment }\end{array}$ & $\begin{array}{l}\text { High } \\
\text { Misalignment }\end{array}$ \\
\hline & $(1)$ & $(2)$ & (3) \\
\hline UnTaxSurp $_{i j t}$ & $\begin{array}{l}3.067^{* * *} \\
(0.000)\end{array}$ & $\begin{array}{c}3.266^{* * *} \\
(0.000)\end{array}$ & $\begin{array}{c}2.821^{* * *} \\
(0.000)\end{array}$ \\
\hline $\operatorname{UnTaxSurp}_{i j t} \times$ Treat $_{i j t} \times$ CbCR $_{t}$ & $\begin{array}{l}1.381^{* * *} \\
(0.006)\end{array}$ & $\begin{array}{c}0.175 \\
(0.781)\end{array}$ & $\begin{array}{l}2.090 * * * \\
(0.002)\end{array}$ \\
\hline Treat $_{i j t} \times$ UnTaxSurp $_{i j t}$ & $\begin{array}{l}-0.240 \\
(0.652)\end{array}$ & $\begin{array}{c}0.620 \\
(0.588)\end{array}$ & $\begin{array}{l}-0.599 \\
(0.369)\end{array}$ \\
\hline$C b C R_{t} \times U n T a x S u r p=i j t$ & $\begin{array}{c}-1.892^{* * *} \\
(0.000)\end{array}$ & $\begin{array}{l}0.005 \\
(0.941)\end{array}$ & $\begin{array}{l}0.073 * \\
(0.066)\end{array}$ \\
\hline Treat $_{i j t} \times C b C R_{t}$ & $\begin{array}{c}0.050 \\
(0.426)\end{array}$ & $\begin{array}{c}-1.863^{* *} \\
(0.045)\end{array}$ & $\begin{array}{c}-1.806^{* * *} \\
(0.003)\end{array}$ \\
\hline MarketValue $_{i j t}$ & $\begin{array}{c}0.032 \\
(0.402)\end{array}$ & $\begin{array}{c}0.041 \\
(0.353)\end{array}$ & $\begin{array}{c}-0.156^{* * *} \\
(0.006)\end{array}$ \\
\hline$B 2 M_{i j t}$ & $\begin{array}{l}-0.073 \\
(0.258)\end{array}$ & $\begin{array}{c}0.055 \\
(0.475)\end{array}$ & $\begin{array}{c}0.016 \\
(0.664)\end{array}$ \\
\hline Return $_{i j t-1}$ & $\begin{array}{l}-0.177^{* * *} \\
(0.000)\end{array}$ & $\begin{array}{c}-0.189^{* * *} \\
(0.000)\end{array}$ & $\begin{array}{c}-0.172 * * * \\
(0.000)\end{array}$ \\
\hline $\begin{array}{l}\text { UnTaxSurp } \times \text { Treat } \times C b C R^{\text {High }}- \\
\text { UnTaxSurp } \times \text { Treat } \times C b C R^{\text {Low }}=0 \\
(\mathrm{p} \text {-value })\end{array}$ & & \multicolumn{2}{|c|}{$\begin{array}{l}2.145 * * * \\
(0.000)\end{array}$} \\
\hline Firm F.E. & Yes & $\mathrm{Y}$ & $\mathrm{Y}$ \\
\hline Country-Year FE & Yes & $\mathrm{Y}$ & Y \\
\hline $\mathrm{N}$ & 54,205 & 27,832 & 26,373 \\
\hline Adjusted $\mathrm{R}^{2}$ & 0.1987 & 0.1508 & 0.2708 \\
\hline 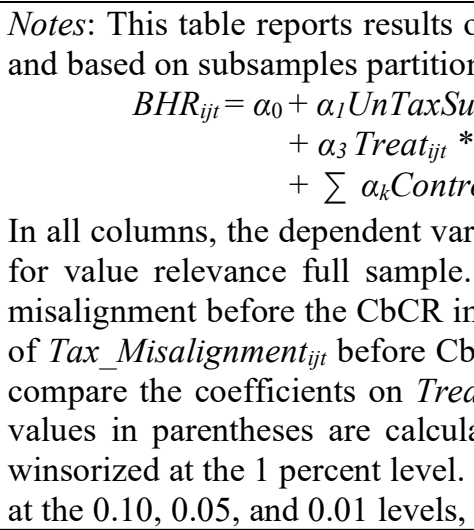 & $\begin{array}{l}\text { mating equation (8 } \\
\text { y the level of misali } \\
\alpha_{2} \text { Treat }_{i j t} * C b C R_{t}^{*} \\
x \text { Surp }_{i j t}+\alpha_{4} C b C R_{t} \\
\sum F E_{d}+\varepsilon_{i j t} \\
\text { is } 12 \text {-month buy-at } \\
\text { olumns (2) and (3 } \\
\text { nentation. A firm h. } \\
\text { doption is below (a } \\
C R \text { using z-tests a } \\
\text { ased on standard } \\
\text { ariables are defined } \\
\text { ctively. }\end{array}$ & $\begin{array}{l}\text { the value relev } \\
\text { the pre-implem } \\
p_{i j t} \\
\text { irp }_{i j t}+\alpha_{5} \text { Treat }_{i j t} \\
\text { turns. In column } \\
\text { tition the sampl } \\
\text { gh) pre-CbCR m } \\
\text { sample median } \\
\text { and high misal } \\
\text { tered by countr } \\
\text { dix A. } *, * *, * * *\end{array}$ & $\begin{array}{l}\text { e defined in Table } 1 \\
\text { riod. } \\
\text { (8) } \\
\text { imate the regression } \\
\text { the firm's level of } \\
t \text { if its average value } \\
\text { tom of the table, we } \\
\text { bsamples. Robust p- } \\
\text { inuous variables are } \\
\text { atistical significance }\end{array}$ \\
\hline
\end{tabular}


Table 8. CbCR and Analysts' Earnings Forecast Accuracy

\begin{tabular}{|c|c|c|c|c|c|c|}
\hline \multirow[t]{2}{*}{$\begin{array}{l}\text { Dependent } \\
\text { Variable }=\end{array}$} & \multicolumn{3}{|c|}{$\begin{array}{c}\text { Pre-tax Income Forecast Error } \\
\text { PRE_AFError }\end{array}$} & \multicolumn{3}{|c|}{$\begin{array}{c}\text { After-tax Income Forecast Error } \\
\text { NET_AFError }{ }_{i j t}\end{array}$} \\
\hline & $\begin{array}{c}\text { Main } \\
\text { Regression }\end{array}$ & $\begin{array}{c}\text { Low } \\
\text { Misalignment }\end{array}$ & $\begin{array}{c}\text { High } \\
\text { Misalignment }\end{array}$ & $\begin{array}{c}\text { Main } \\
\text { Regression }\end{array}$ & $\begin{array}{c}\text { Low } \\
\text { Misalignment }\end{array}$ & $\begin{array}{c}\text { High } \\
\text { Misalignment }\end{array}$ \\
\hline & $(1)$ & (2) & (3) & (4) & (5) & (6) \\
\hline Treat $_{i j t} \times \boldsymbol{C b C R}_{t}$ & $\begin{array}{c}-0.003 * * * \\
(0.000)\end{array}$ & $\begin{array}{l}-0.001 * \\
(0.051)\end{array}$ & $\begin{array}{c}-0.005 * * * \\
(0.000)\end{array}$ & $\begin{array}{c}-0.003 * * * \\
(0.000)\end{array}$ & $\begin{array}{c}-0.001 * * \\
(0.013)\end{array}$ & $\begin{array}{c}-0.004 * * * \\
(0.000)\end{array}$ \\
\hline SalesGrowth $_{i j t}$ & $\begin{array}{c}-0.005^{* * *} \\
(0.002)\end{array}$ & $\begin{array}{c}-0.003 * * \\
(0.039)\end{array}$ & $\begin{array}{c}-0.009 * * * \\
(0.002)\end{array}$ & $\begin{array}{c}-0.005^{* * *} \\
(0.002)\end{array}$ & $\begin{array}{c}-0.003 * * \\
(0.035)\end{array}$ & $\begin{array}{c}-0.007 * * * \\
(0.001)\end{array}$ \\
\hline PRE_AFDisp $p_{i j t}$ & $\begin{array}{c}0.005^{* * *} \\
(0.006)\end{array}$ & $\begin{array}{c}0.001^{* *} \\
(0.050)\end{array}$ & $\begin{array}{c}0.007 * * * \\
(0.002)\end{array}$ & $\begin{array}{c}0.003 * * * \\
(0.000)\end{array}$ & $\begin{array}{l}0.001 * \\
(0.064)\end{array}$ & $\begin{array}{c}0.004 * * * \\
(0.000)\end{array}$ \\
\hline AnalystFollowing $_{i j t}$ & $\begin{array}{l}0.000 * * \\
(0.016)\end{array}$ & $\begin{array}{l}-0.000 \\
(0.137)\end{array}$ & $\begin{array}{l}0.000 * * \\
(0.011)\end{array}$ & $\begin{array}{l}0.000^{* * *} \\
(0.005)\end{array}$ & $\begin{array}{l}-0.000 \\
(0.201)\end{array}$ & $\begin{array}{l}0.000 * * * \\
(0.003)\end{array}$ \\
\hline ShareTurnover $_{i j t}$ & $\begin{array}{c}0.002 * * * \\
(0.004)\end{array}$ & $\begin{array}{c}0.001 * * * \\
(0.003)\end{array}$ & $\begin{array}{c}0.004 * * * \\
(0.003)\end{array}$ & $\begin{array}{c}0.002 * * * \\
(0.000)\end{array}$ & $\begin{array}{c}0.001 * * * \\
(0.001)\end{array}$ & $\begin{array}{c}0.003 * * * \\
(0.000)\end{array}$ \\
\hline Leverage $_{i j t}$ & $\begin{array}{r}-0.006^{*} \\
(0.098)\end{array}$ & $\begin{array}{l}-0.001 \\
(0.790)\end{array}$ & $\begin{array}{l}-0.007 \\
(0.208)\end{array}$ & $\begin{array}{c}-0.005^{* *} \\
(0.024)\end{array}$ & $\begin{array}{l}-0.001 \\
(0.550)\end{array}$ & $\begin{array}{l}-0.006^{*} \\
(0.054)\end{array}$ \\
\hline MarketValue $_{i j t}$ & $\begin{array}{c}-0.025^{* * *} \\
(0.000)\end{array}$ & $\begin{array}{c}-0.007 * * \\
(0.022)\end{array}$ & $\begin{array}{c}-0.036 * * * \\
(0.000)\end{array}$ & $\begin{array}{c}-0.022 * * * \\
(0.000)\end{array}$ & $\begin{array}{c}-0.005 * * \\
(0.024)\end{array}$ & $\begin{array}{c}-0.032 * * * \\
(0.000)\end{array}$ \\
\hline $\begin{array}{l}\text { Treat } \times C b C R^{\text {High }}- \\
\text { Treat } \times C b C R^{\text {Low }}=0 \\
(\mathrm{p} \text {-value })\end{array}$ & \multicolumn{3}{|c|}{$\begin{array}{c}-0.004 * * * \\
(0.000)\end{array}$} & & \multicolumn{2}{|c|}{$\begin{array}{c}-0.003 * * * \\
(0.000)\end{array}$} \\
\hline Firm F.E. & Yes & Yes & Yes & Yes & Yes & Yes \\
\hline Country-Year FE & Yes & Yes & Yes & Yes & Yes & Yes \\
\hline $\mathrm{N}$ & 40,123 & 20,198 & 19,925 & 40,123 & 20,198 & 19,925 \\
\hline Adjusted $\mathrm{R}^{2}$ & 0.4851 & 0.2348 & 0.4909 & 0.4550 & 0.2183 & 0.4805 \\
\hline $\begin{array}{l}\text { Notes: This table rep } \\
\text { defined in Table } 1 \text { a } \\
\text { Tax_Misalignme } \\
\text { In columns (1)-(3), } \\
\text { error. In columns (4 } \\
\text { forecast error. In co } \\
\text { and (3), we partition } \\
\text { has low (high) pre-( } \\
\text { (above) the sample } \\
\text { columns (5) and ( } \\
\text { implementation. At } \\
\text { high misalignment } \\
\text { country. All continu }\end{array}$ & $\begin{array}{l}t_{i j t}=\gamma_{0}+\gamma_{I} T r \\
\text { e adapt equat } \\
\text {-(6), we adap } \\
\text { umn (1), we e } \\
\text { the sample b } \\
\text { bCR misalig } \\
\text { tedian. In col } \\
\text { ), we partiti } \\
\text { ne bottom of } \\
\text { ubsamples. R } \\
\text { us variables a } \\
\text { l significance }\end{array}$ & $\begin{array}{l}a t_{i j t} * C b C R_{t}+\sum \\
\text { n (7) by replacir } \\
\text { equation (7) by r } \\
\text { timate the regres } \\
\text { sed on the firm's } \\
\text { ment if its avera } \\
\mathrm{mn}(4) \text {, we estim } \\
\mathrm{n} \text { the sample } \mathrm{t} \\
\text { te table, we com } \\
\text { bust p-values in } \\
\text { e winsorized at } \mathrm{t} \\
\text { at the } 0.10,0.05\end{array}$ & $\begin{array}{l}\text { ons of equation } \\
\text { d by the level of } \\
{ }_{k} \text { Control }_{k}+\sum F \\
\text { the dependent } \\
\text { placing the depe } \\
\text { ion for the analy } \\
\text { level of misaligi } \\
\text { e value of Tax } \\
\text { te the regression } \\
\text { sed on the fir } \\
\text { are the coefficie } \\
\text { parentheses are } \\
\text { e } 1 \text { percent level } \\
\text { and } 0.01 \text { levels, }\end{array}$ & $\begin{array}{l}\text { ) based on the } \\
\text { nisalignment } \\
E_{d}+\varepsilon_{i j t} \quad \text { (7) } \\
\text { ariable using } \\
\text { dent variable } \\
t \text { forecast acc } \\
\text { nent before } \mathrm{t} \\
\text { Iisalignment } \\
\text { or the analys } \\
\text { 's level of } \\
\text { s on Treat } \times C \\
\text { alculated bas } \\
\text { All variables } \\
\text { espectively. }\end{array}$ & $\begin{array}{l}\text { Inalyst forecast } \\
\text { the pre-implem } \\
\text { alysts' pre-tax e } \\
\text { sing analysts' at } \\
\text { acy full sample } \\
\text { CbCR implem } \\
\text { efore CbCR ad } \\
\text { orecast accurac } \\
\text { isalignment be } \\
C R \text { using z-test } \\
\text { on standard er } \\
\text { e defined in Ap }\end{array}$ & $\begin{array}{l}\text { ccuracy sample } \\
\text { entation period. } \\
\text { arnings forecast } \\
\text { er-tax earnings } \\
\text { In columns (2) } \\
\text { ntation. A firm } \\
\text { ption is below } \\
\text { full sample. In } \\
\text { ore the CbCR } \\
\text { across low and } \\
\text { or clustered by } \\
\text { endix A. *, **, }\end{array}$ \\
\hline
\end{tabular}


Table 9. CbCR and Value Relevance of Earnings

\begin{tabular}{|c|c|c|c|}
\hline \multirow[t]{2}{*}{ Dependent Variable $=$} & \multicolumn{3}{|c|}{$\begin{array}{l}\text { 12-month Buy-and-hold Return } \\
\qquad B H R_{i j t}\end{array}$} \\
\hline & Main Regression & Low Misalignment & High Misalignment \\
\hline & $(1)$ & $(2)$ & $(3)$ \\
\hline EarnSurp $_{t}$ & $\begin{array}{c}1.624 * * * \\
(0.000)\end{array}$ & $\begin{array}{c}1.915 * * * \\
(0.000)\end{array}$ & $\begin{array}{c}1.441 * * * \\
(0.000)\end{array}$ \\
\hline EarnSurp $_{t} \times$ Treat $_{t} \times C b C R_{t}$ & $\begin{array}{c}0.346 \\
(0.171)\end{array}$ & $\begin{array}{c}-0.452 * \\
(0.055)\end{array}$ & $\begin{array}{c}0.655 * * \\
(0.028)\end{array}$ \\
\hline Treat $_{t} \times$ EarnSurp $_{t}$ & $\begin{array}{c}0.032 \\
(0.878)\end{array}$ & $\begin{array}{l}0.453^{* *} \\
(0.043)\end{array}$ & $\begin{array}{l}-0.144 \\
(0.440)\end{array}$ \\
\hline $\mathrm{CbCR}_{t} \times$ EarnSurp $_{t}$ & $\begin{array}{c}-0.386^{* *} \\
(0.020)\end{array}$ & $\begin{array}{l}-0.318 \\
(0.358)\end{array}$ & $\begin{array}{c}-0.443 * * \\
(0.017)\end{array}$ \\
\hline Treat $_{t} \times C b C R_{t}$ & $\begin{array}{c}0.047 \\
(0.438)\end{array}$ & $\begin{array}{c}0.007 \\
(0.922)\end{array}$ & $\begin{array}{l}0.071^{*} \\
(0.059)\end{array}$ \\
\hline MarketValue $_{t}$ & $\begin{array}{c}0.027 \\
(0.445)\end{array}$ & $\begin{array}{c}0.011 \\
(0.806)\end{array}$ & $\begin{array}{c}-0.147 * * * \\
(0.007)\end{array}$ \\
\hline$B 2 M_{t}$ & $\begin{array}{l}-0.076 \\
(0.190)\end{array}$ & $\begin{array}{c}0.038 \\
(0.550)\end{array}$ & $\begin{array}{c}0.016 \\
(0.637)\end{array}$ \\
\hline Return $_{t-1}$ & $\begin{array}{c}-0.180^{* * * *} \\
(0.000) \\
\end{array}$ & $\begin{array}{c}-0.193 * * * \\
(0.000) \\
\end{array}$ & $\begin{array}{c}-0.172 * * * \\
(0.000) \\
\end{array}$ \\
\hline \multicolumn{2}{|l|}{$\begin{array}{l}\text { UnTaxSurp }_{t} \times \text { Treat } \times \mathrm{CbCR}^{\text {High }}- \\
\text { UnTaxSurp } \\
\text { (p-value) }\end{array}$} & \multicolumn{2}{|c|}{$\begin{array}{l}1.107 * * * \\
(0.000)\end{array}$} \\
\hline Firm F.E. & $\mathrm{Y}$ & $\mathrm{Y}$ & $\mathrm{Y}$ \\
\hline Country-Year FE & $\mathrm{Y}$ & Y & $\mathrm{Y}$ \\
\hline$N$ & 54,205 & 27,832 & 26,373 \\
\hline $\operatorname{Adj}-R^{2}$ & 0.2210 & 0.1715 & 0.2943 \\
\hline \multicolumn{4}{|c|}{ 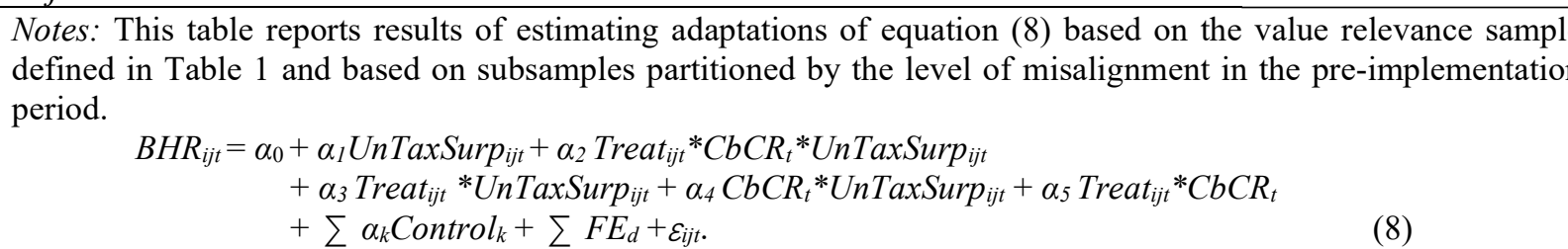 } \\
\hline \multicolumn{4}{|c|}{$\begin{array}{l}\text { In all columns, we adapt equation (8) by replacing unexplained tax surprise (UnTaxSurp) using earnings surprise } \\
\text { (EarnSurp). The dependent variable is } 12 \text {-month buy-and-hold returns. In column }(1) \text {, we estimate the regression } \\
\text { for value relevance full sample. In columns }(2) \text { and ( } 3 \text { ), we partition the sample based on the firm's level of } \\
\text { misalignment before the CbCR implementation. A firm has low (high) pre-CbCR misalignment if its average value } \\
\text { of Tax_Misalignmentijt before CbCR adoption is below (above) the sample median. At the bottom of the table, we } \\
\text { compare the coefficients on Treat } \times C b C R \text { using z-tests across low and high misalignment subsamples. Robust p- } \\
\text { values in parentheses are calculated based on standard error clustered by country. All continuous variables are } \\
\text { winsorized at the } 1 \text { percent level. All variables are defined in Appendix A. *, }{ }^{* *}, * * * \text { indicate statistical significance } \\
\text { at the } 0.10,0.05 \text {, and } 0.01 \text { levels, respectively. }\end{array}$} \\
\hline
\end{tabular}

